2015

\title{
A PETROPHYSICAL EVALUATION OF THE TRENTON-BLACK RIVER FORMATION OF THE MICHIGAN BASIN
}

Lu Yang

Michigan Technological University

Follow this and additional works at: https://digitalcommons.mtu.edu/etds

Part of the Geology Commons

Copyright 2015 Lu Yang

\section{Recommended Citation}

Yang, Lu, "A PETROPHYSICAL EVALUATION OF THE TRENTON-BLACK RIVER FORMATION OF THE MICHIGAN BASIN", Master's Thesis, Michigan Technological University, 2015.

https://doi.org/10.37099/mtu.dc.etds/914

Follow this and additional works at: https://digitalcommons.mtu.edu/etds

Part of the Geology Commons 


\title{
A PETROPHYSICAL EVALUATION OF THE TRENTON-BLACK RIVER FORMATION OF THE MICHIGAN BASIN
}

\author{
By \\ Lu Yang \\ A THESIS \\ Submitted in partial fulfillment of the requirements for the degree of \\ MASTER OF SCIENCE \\ In Geology \\ MICHIGAN TECHNOLOGICAL UNIVERSITY \\ 2015 \\ (C) $2015 \mathrm{Lu}$ Yang
}


This thesis has been approved in partial fulfillment of the requirements for the Degree of MASTER OF SCIENCE in Geology.

Department of Geological and Mining Engineering and Sciences

\author{
Thesis Advisor: $\quad$ Wayne D. Pennington
}

Committee Member: $\quad$ Mir Sadri

Committee Member: $\quad$ James R. Wood

Department Chair: John S. Gierke 


\section{Table of Contents}

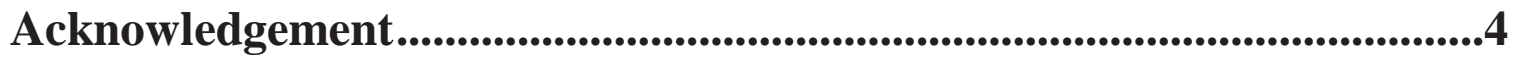

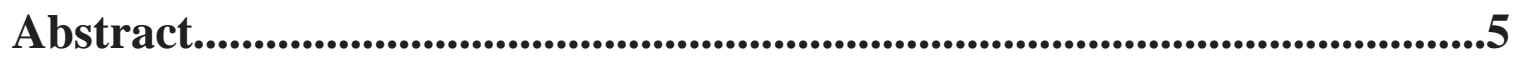

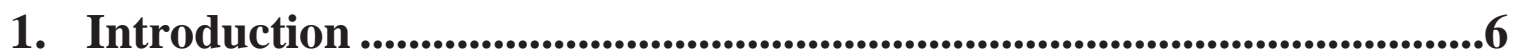

2. Geology of Trenton-Black River Formation.........................................66

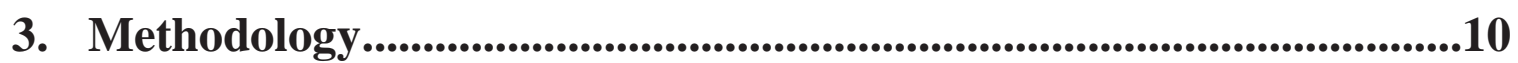

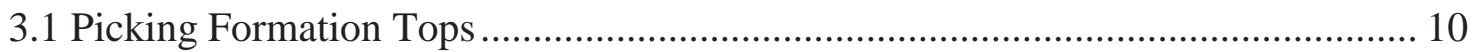

3.2 Crossplot and Mineral Identification .............................................................. 13

4. Thomas Stieber Method.......................................................................................30

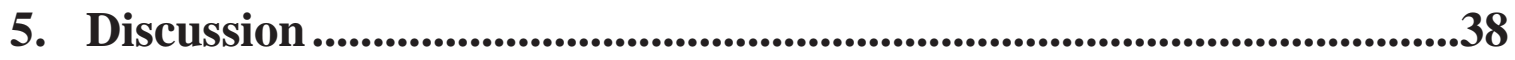

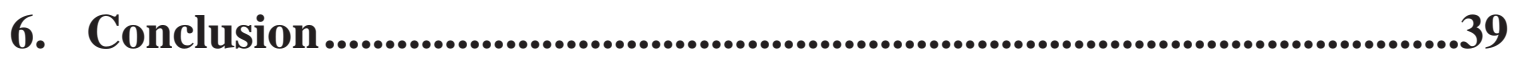

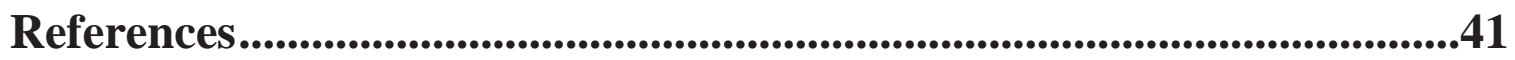

Appendix I: Crossplots \& Mineral Identification ....................................42

Appendix II: Thomas Stieber (Thomas and Stieber 1975).....................49 


\section{Acknowledgement}

I would like to express the deepest appreciation to my advisor Dr. Wayne D. Pennington for his expert guidance and full support. His experience and ability improved my research skills. My thesis work would not have been possible without his help and incredible patience.

I would like to thank my committee members, Professor James R. Wood and Professor Mir Sadri, for helping me during my graduate years and their helpful suggestions and comments on my research work. I am also thankful to Carol J. Asiala for helping me obtain the data and guiding me through the Surfer software.

Thanks also go to my fellow graduate students, especially Nayyer Islam; I obtained much benefit from working with him on the Powerlog software, and he gave me a lot of help and advice to my research. I also have to express my appreciation to Qiang Guo and Yeliz Egemen; with your support, I finally overcome the difficulties during the research and finished it.

I would also like to thank my parents and friends for their support and they always encourage me to be the best. I am very blessed to have you all in my life. 


\section{Abstract}

This work is conducted to study the geological and petrophysical features of the TrentonBlack River limestone formation. Log curves, crossplots and mineral identification methods using well-log data are used to determine the components and analyze changes in lithology. Thirty-five wells from the Michigan Basin are used to define the mineralogy of Trenton-Black River limestone. Using the different responses of a few log curves, especially gamma-ray, resistivity and neutron porosity, the formation tops for the Utica shale, the Trenton limestone, the Black River limestone and the Prairie du Chien sandstone are identified to confirm earlier authors' work and provide a basis for my further work. From these, an isopach map showing the thickness of Trenton-Black River formation is created, indicating that its maximum thickness lies in the eastern basin and decreases gradually to the west. In order to obtain more detailed lithological information about the limestone formations at the thirty-five wells, (a) neutron-density and neutron-sonic crossplots, (b) mineral identification methods, including the M-N plot, MID plot, Qmaa vs. $\mathrm{U}_{\text {maa }}$ MID plot, and the PEF plot, and (c) a modified mineral identification technique are applied to these wells. From this, compositions of the Trenton-Black River formation can be divided into three different rock types: pure limestone, partially dolomitized limestone, and shaly limestone. Maps showing the fraction of dolomite and shale indicate their geographic distribution, with dolomite present more in the western and southwestern basin, and shale more common in the north-central basin. Mineral identification is an independent check on the distribution found from other authors, who found similar distributions based on core descriptions.

The Thomas Stieber method of analysis is best suited to sand-shale sequences, interpreting three different distributions of shale within sand, including dispersed, laminated and structural. Since this method is commonly applied in clastic rocks, my work using the Thomas Stieber method is new, as an attempt to apply this technique, developed for clastics, to carbonate rocks. Based on the original assumption and equations with a corresponding change to the Trenton-Black River formation, feasibility of using the Thomas Stieber method in carbonates is tested. A graphical display of gamma-ray versus 
density porosity, using the properties of clean carbonate and pure shale, suggests the presence of laminated shale in fourteen wells in this study. Combined with Wilson's study (2001), it is safe to conclude that when shale occurs in the Trenton-Black River formation, it tends to be laminated shale.

\section{Introduction}

The Trenton-Black River formation is a Middle Ordovician carbonate present throughout the Michigan Basin, a sedimentary and structural basin located on the Lower Peninsula. The basin depocenter is located in near Saginaw Bay. The basin is a simple, undeformed cratonic basin with a radius of one hundred and fifty $\mathrm{km}$ and about five $\mathrm{km}$ of depth. (Howell and van der Pluijm 1990) Several structural elements flank the southern portion of the Michigan Basin: Kankakee Arch, Cincinnati Arch and Findlay Arch, serving as boundaries between the Michigan Basin and surrounding Illinois and Appalachian basins.

Many formations in the Michigan Basin are sources of petroleum. The Michigan basin extends into Ontario, Canada, where operators are making an effort to develop the oil and gas potential. Much of the increasing drilling activity in the Michigan basin can be attributed to the exploration and production of the Trenton-Black River formation. In 2013, the leader of oil exploration was in the Trenton-Black River formation in Jackson, Lenawee and Washtenaw Counties. During mid-November of 2014, forty-six of one hundred and twenty-five wells drilled in the state were located in the three counties (Talley 2014).

\section{Geology of Trenton-Black River Formation}

According to a study by Wylie et al. (2004) more than three thousand and seven hundreds wells have been drilled in the Ordovician Trenton-Black River formations of the Michigan basin, and most Trenton well penetrations and Trenton-Black River production wells fell on southeastern basin. In order to obtain more detailed information of Trenton-Black River formations, isopach and topographic maps of Trenton-Black River formation are prepared to map the trend of the thickness and the distribution of dolomitization and shale. The 
mineral identification is an independent check on the distribution found from Wylie et al. (2004) and Ives (1960). Logs for thirty-five wells within the Michigan Basin are used in this work. Figure 2.1 presents the thickness map and the depth contour map of the TrentonBlack River formation. The background color represents the top depth of Trenton limestone, which shows that the deepest top is at the center, but the gray contour lines display that Trenton-Black River formation has its maximum thickness in the eastern basin and decreases gradually to the western part. The maximum thickness is not at the center but in the eastern basin, and is also not at the location of the deepest portion of the Trenton formation. In eastern Michigan, the maximum thickness of the formation is about one thousand feet. In the western and southwestern Michigan, the formation is less than four hundred feet thick (Ives 1960).

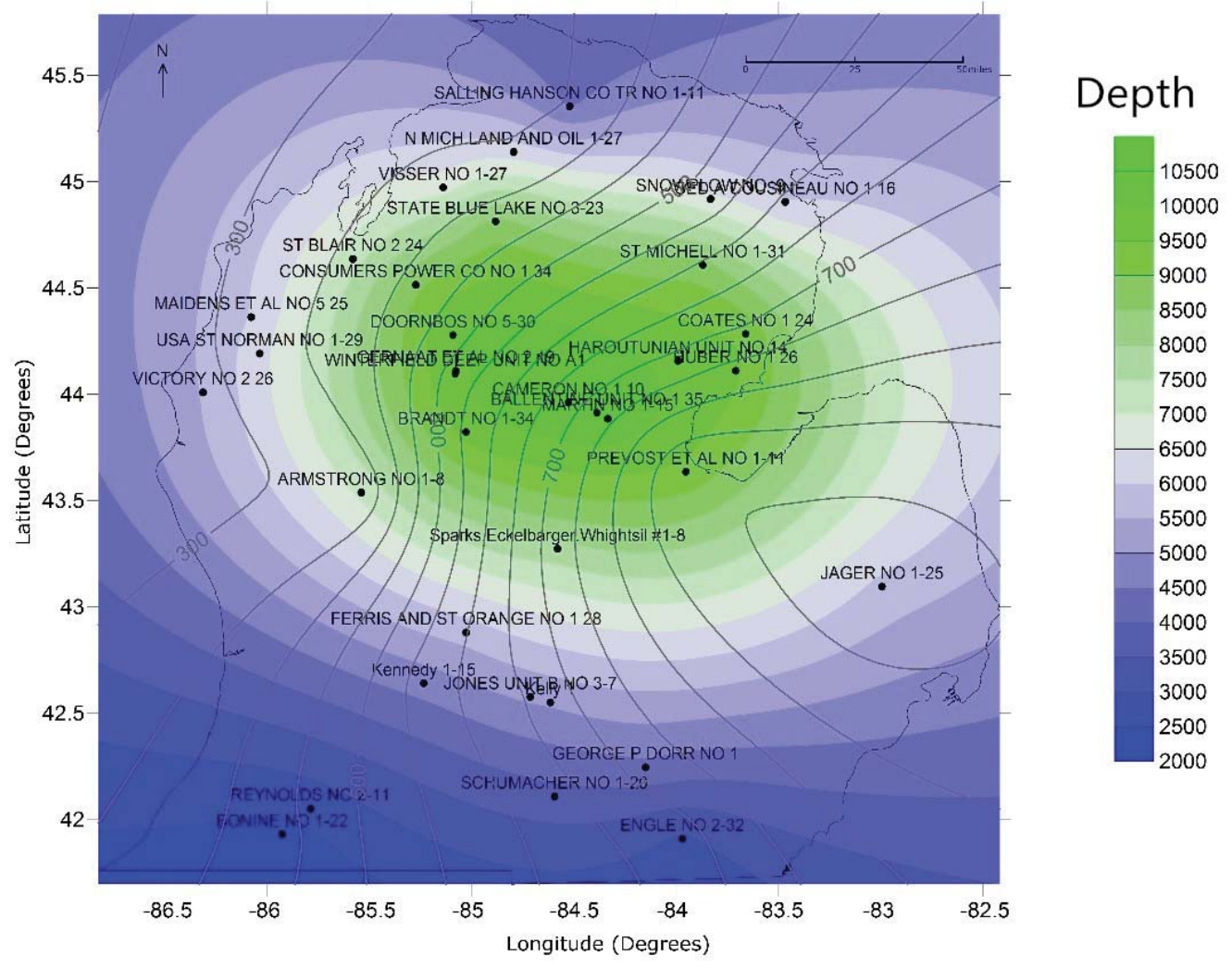

Figure 2.1 Thickness and depth contour map of Trenton-Black River formation. The gray contour lines display the thickness in feet with an interval of fifty ft. The background color displays the tops of Trenton limestone with an interval of five hundred $\mathrm{ft}$. 
The Trenton-Black River formation is primarily a brown to gray crystalline limestone. Two geologic maps are created in order to study the geographic distribution of dolomite and shale within it. For the first map, based on the modified mineral identification (explained in Chapter 4), the fractions of four minerals, limestone, dolomite, sandstone and shale are calculated. Not all wells have the PEF log required for this technique, so there are twentysix wells used for this calculation. Figure 2.2 displays the average dolomite fraction in the Trenton-Black River formation based on those twenty-six wells. The higher fraction of dolomite lies in the western and southwestern portion of the basin and the lower fraction of dolomite in the southeastern and central basin. These results are consistent with an earlier study by Ives (1960) that found limestone and dolomite both present in the southeastern and south central basin, but in the western and southwestern basin, the dolomite concentration is much higher.

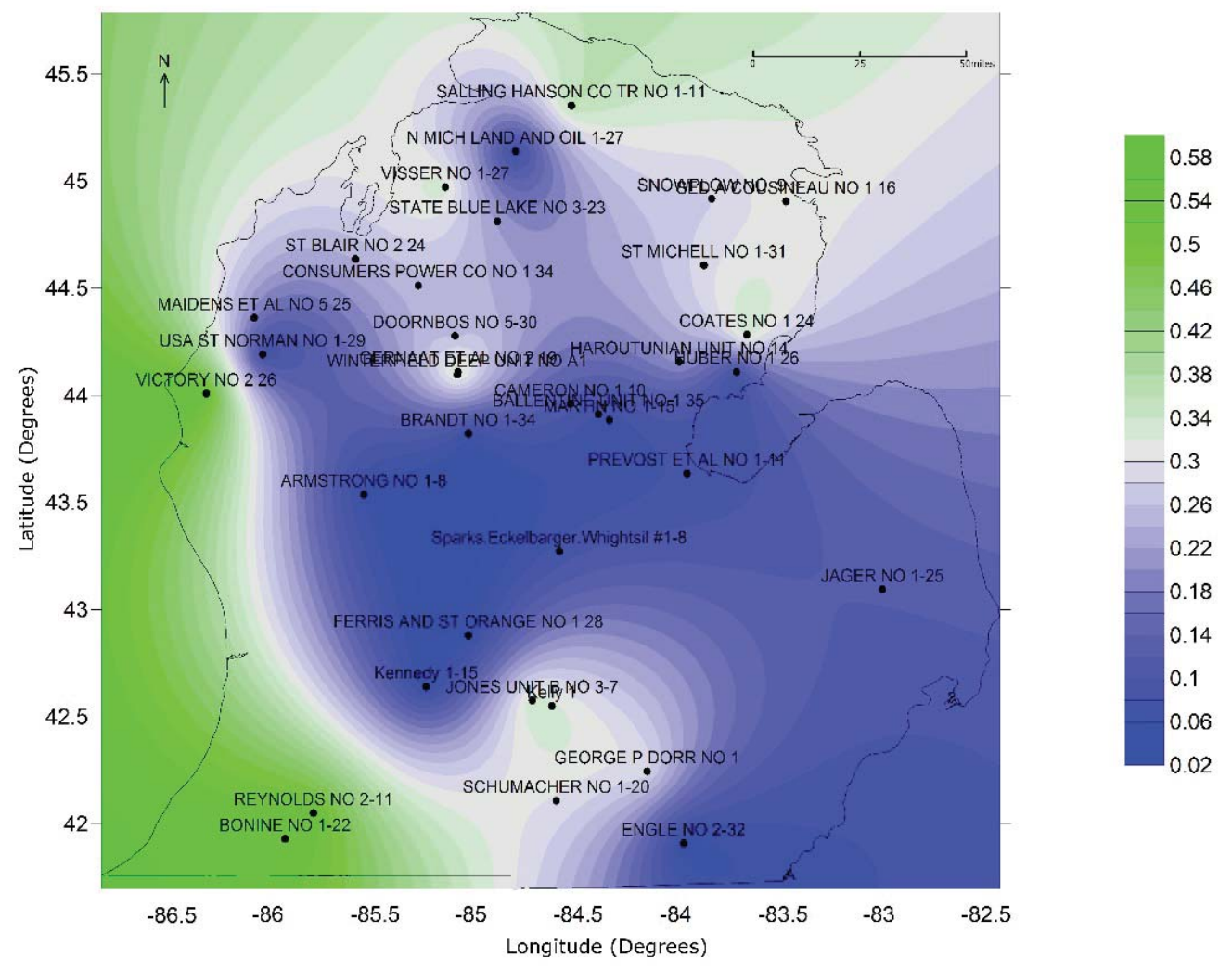

Figure 2.2 Contour map of Trenton-Black River formation indicating dolomite fraction by color. 
For the second map, shale content based on twenty-six wells are displaying with modified mineral identification. The basal unit of Trenton-Black River formation is a very thin unit, which contains gray to green calcareous shale, lying unconformably over older Ordovician and Cambrian from the west to east. The entire unit of Trenton limestone is about thirty feet, and a black dolomitic shale bed is at its base. Figure 2.3 displays the average shale fraction in the Trenton-Black River formation. The higher shale fraction is in the north central part of the basin, which is at the deepest point for the top of Trenton limestone formation.

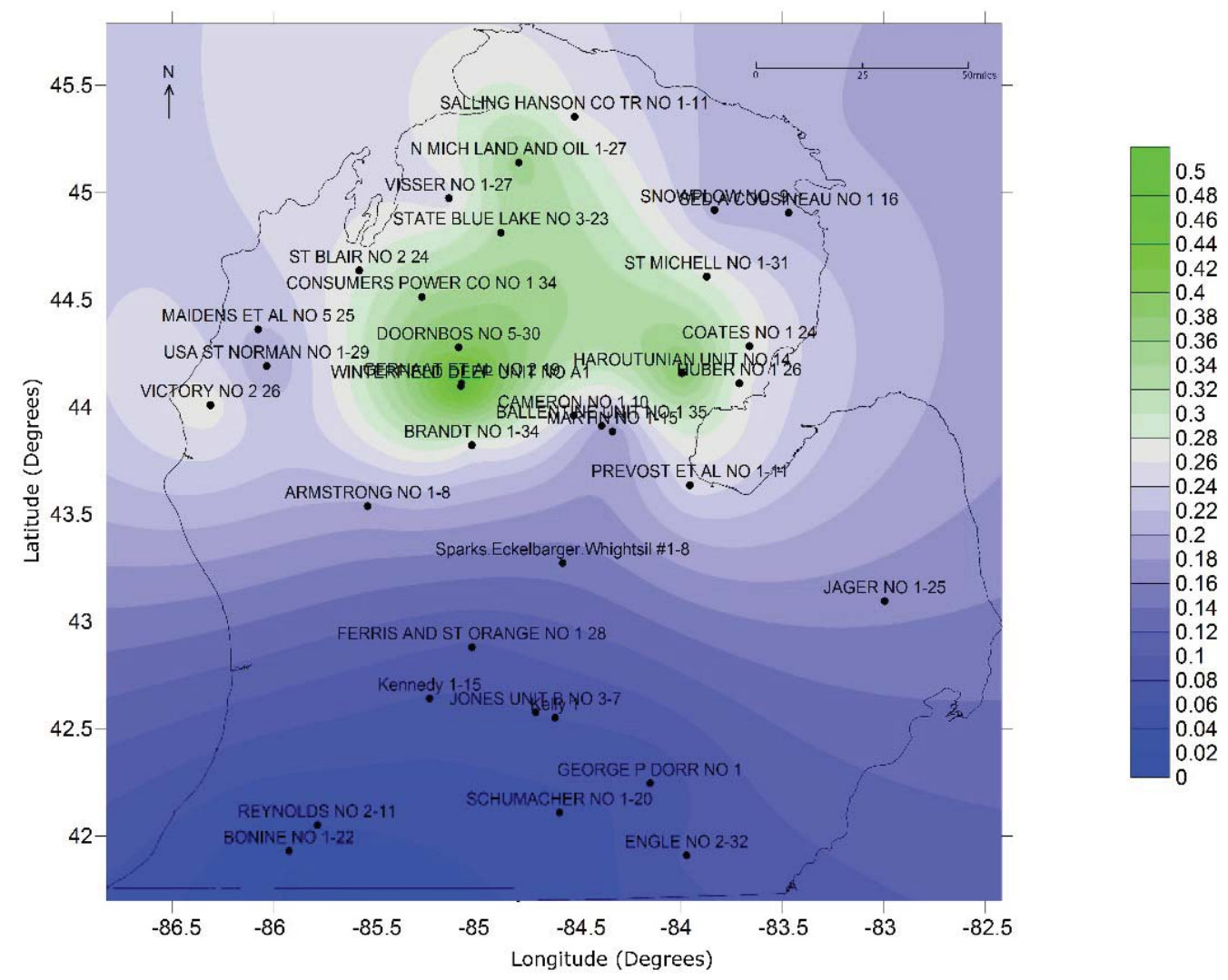

Figure 2.3 Contour map of Trenton-Black River formation showing the average fraction of shale. 


\section{Methodology}

In order to obtain the detailed lithological features of the Trenton-Black River formation displayed in the maps shown in Figures 2.2 and 2.3, a determination of mineralogy and porosity is made, particularly being concerned with the mineral types and their fractions. Thirty-five wells are used in this analysis from log data available through the Michigan Department of Environmental Quality. The compensated neutron porosity, sonic log, bulk density, density porosity, gamma-ray log and PEF log are required for the analyses presented in this section. The process started with picking tops of the formations from the logs. Then, I used conventional crossplotting techniques to determine primary lithology at the wells selected for this study. Using another technique for "modified mineral determination," the results shown in Figures 2.2 and 2.3 are obtained; these maps are compared with the results obtained from the conventional techniques as well.

\subsection{Picking Formation Tops}

The Trenton limestone in the Michigan basin is overlain by Utica shale, which is a traditional shale with high quartz and clay content and very little carbonate. The Utica shale presents higher gamma-ray response than Trenton limestone due to the clay content, as radioactive elements tend to concentrate in the impermeable shale, and are at lower concentrations in permeable carbonates and sands. Resistivity of Utica shale is lower than Trenton limestone because of the organic material and its higher conductivity. These traits provide good indicators for picking the base of the Utica shale (the top of the Trenton limestone). Additionally, Utica shale presents greater sonic transit times than Trenton limestone; this can be attributed to the presence of clay, bound water and higher porosity in the shale. With the presence of the bound water in clay, Utica shale has a higher neutron porosity. These four log curves can be very useful for identifying the contact between Utica shale and Trenton limestone. 
In general, Trenton-Black River limestone exhibits low gamma-ray response in clean limestone. But there are some exceptions of high amplitude spikes within it due to clay and organic material. The resistivity response of the Trenton-Black River limestone is also variable. Sonic transit time in Trenton-Black River limestone is lower due to the low porosity, and some degree of dolomitization. On the other hand, the density porosity does not provide a good indication of the boundary between Utica shale and Trenton-Black River limestone. Since there is no hydrocarbon effect or bound water in clay, most of the wells in Trenton-Black River limestone show lower neutron porosity response than Utica shale (Banas 2011).

The boundary between the Utica shale and the Trenton-Black River limestone is identified from the available log data, in order to confirm earlier authors' work and provide a basis for my other efforts. Two log plots of well BONINE NO 1-22 and BRAND NO 1-34 are shown in Figure 3.1 as examples. Both of these displays include three formations: Utica shale, Trenton limestone and Black River limestone. The green line in the first track is the gamma-ray log; it is much higher in Utica shale than it is in Trenton-Black River formation. The second track displays the resistivity logs, which are higher in Trenton-Black River limestone than in Utica shale. The third track displays the porosity logs, including density porosity, neutron porosity and average porosity (computed by averaging the other two); Utica shale has higher porosity readings than the two limestone formations. The pink curve in the fourth track is sonic transit time, which due to the higher porosity is greater in Utica shale than in Trenton-Black River limestone. (Schlumberger 1991) 


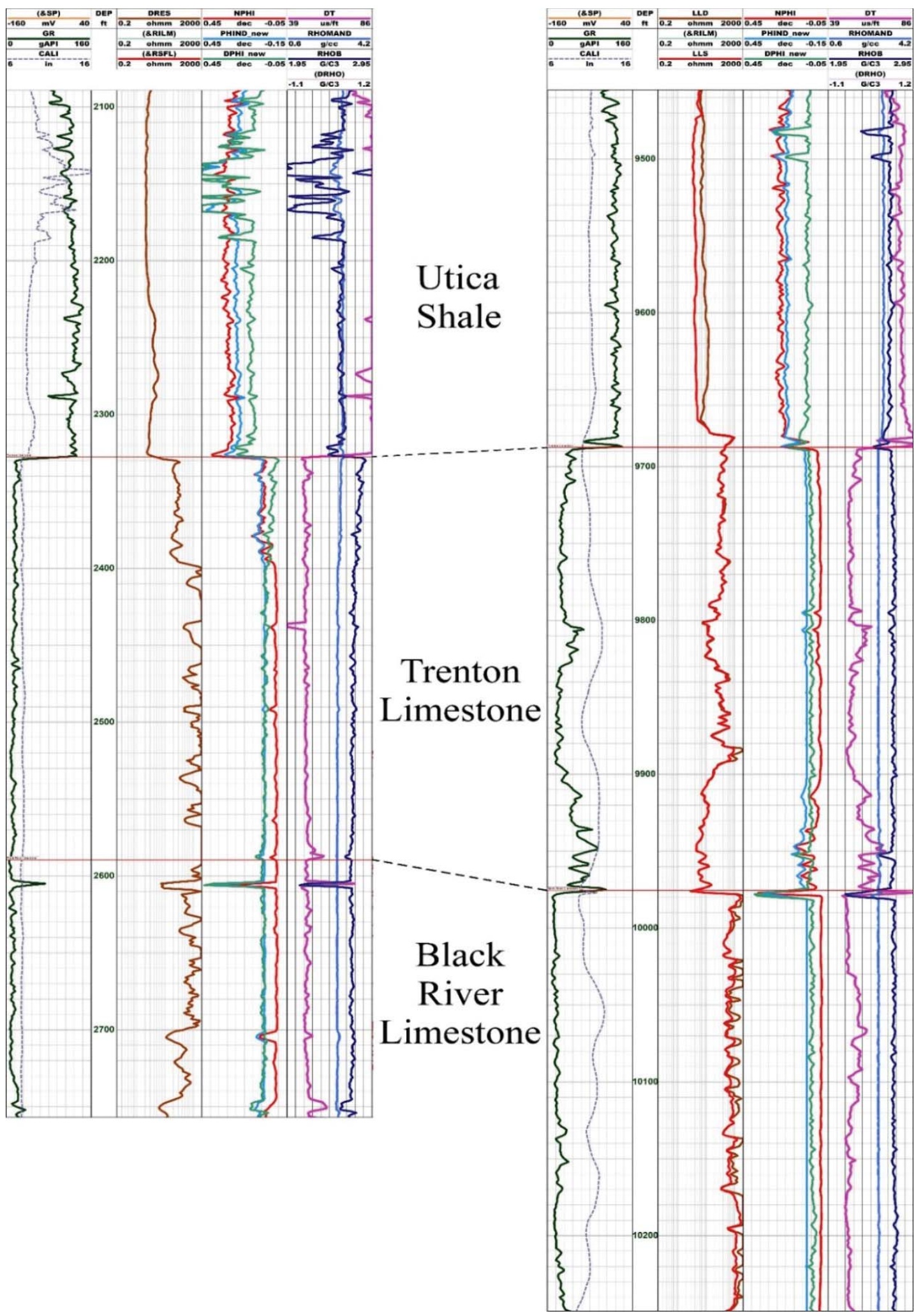

(a)

(b) 
Figure 3.1 Log plots with Utica shale, Trenton limestone and Black River limestone formations, dotted lines are the tops of Trenton limestone and Black River limestone formations. (a) Log plot of well BONINE NO 1-22, the depth of top of the Trenton limestone is $2328 \mathrm{ft}$; the depth of top of the Black River limestone is $2590 \mathrm{ft}$. (b) Log plot of well BRANDT NO 1-34.

\subsection{Crossplot and Mineral Identification}

Crossplots provide good tools to compare various log responses to porosity and lithology, including shale content. In order to identify the presence of shale and recognize lithology changes in the Trenton-Black River formation, the neutron-density and neutron-sonic crossplots were used in this work. To further clarify the mineral mixtures, the M-N plot, the MID plot, the @maa Vs. $\mathrm{U}_{\text {maa }}$ MID plot, the PEF plot and a modified mineral identification were used.

The neutron-density crossplot with a color indicator is derived from three logs: the bulk density, neutron porosity and gamma-ray logs. The density log contains a radioactive source and two detectors, the radioactive source is applied to the borehole wall and emits gamma-rays into the formation. The bulk density tool responds to the electron density of a formation by measuring the attenuation of gamma-rays between a source and a detector. The electron density, in turn, is related to the bulk density. The bulk density depends on the density of the fluid, the density of the matrix, and the formation porosity. If the density tool is calibrated in freshwater-filled formations, the apparent bulk density is related to the electron density index. If the conditions in the borehole and formation match the calibration conditions, the apparent bulk density is identical to actual bulk density. Neutron logs measure the hydrogen population in a formation, and the result is related to porosity. Specifically, the compensated neutron-porosity logging tool measures the size of a neutron cloud from a neutron source that emits fast neutrons and two neutron detectors. Because shale contains bound water in its structure, the neutron tool responds to the hydrogen in the 
bound water, and reads higher neutron porosity values in the shale. Gamma-ray logging records the natural radioactivity of a formation arising from uranium (U), thorium (Th), and potassium $(\mathrm{K})$. These three elements tend to be concentrated in shales, so the gammaray $\log$ is the most common shale volume indicator. There are three lithological lines typically overlain in the neutron-density crossplot, showing sandstone, limestone, and dolomite lines. We generally add color to the points for gamma-ray values as a shale indicator. From the trend of our data, we can estimate the mineral composition of the formation under study.

The neutron-sonic crossplot with a color indicator is derived from three logs: the sonic, neutron porosity and gamma-ray logs. The sonic logs, also known as sonic travel-time logs, recording a sound pulse as it passes a pair of receivers, usually provided in terms of slowness (inverse velocity) in $\mu \mathrm{s} / \mathrm{ft}$. The speed of sound in rocks is influenced by physical properties, including the formation and fluid type. The transmitter emits a sound pulse once or twice per second, and the first arrival wave is detected by the receivers. The time elapsed between the arrival of the first arrival wave at two receivers is the travel time. The crossplot is similar to the neutron-density crossplot, in that lines are commonly overlain indicating limestone, sandstone, and dolomite. Color is added from gamma-ray logs as a shale indicator.

The M-N plot is a method of combining the three porosity logs: neutron porosity, density porosity and sonic porosity to compute the lithology identifiers $\mathrm{M}$ and $\mathrm{N}$. We use crossplots of sonic-density and neutron-density to, in a sense, normalize to density and compare the normalized values of sonic and neutron, where $\mathrm{M}$ is the slope of the individual lithology lines on the sonic-density crossplot and $\mathrm{N}$ is the slope of the individual lithology lines on the neutron-density crossplot; plotting data on an M-N plot provides one estimate of lithology. The equations and property values I used are provided in Appendix I (Schlumberger 1991).

For the MID plot, the apparent total porosity, apparent matrix transit time and apparent grain density are required. By assuming the fluid density and using the measured bulk 
density, we can obtain the apparent matrix density. The apparent matrix sonic velocity is determined through the Wyllie Time-Average equation using the measured sonic velocity and an assumed fluid velocity. A crossplot of parameters derived from these values is used in the MID plot to provide another estimate of lithology.

The Qmaa vs. $\mathrm{U}_{\text {maa }}$ MID plot is similar to the MID plot, this time identifying lithology with data from the litho-density (including the photo-electric effect, or PEF) log. It uses the apparent matrix grain density (RHOMAND) and the apparent matrix volumetric cross section for the photo-electric effect (UMA). All the equations and parameters for the plots are in Appendix I (Schlumberger 1991).

I applied all the crossplots and mineral identification methods to the selected 35 wells (26 wells for the techniques requiring PEF). The results can be categorized into three different types. First, some wells display mostly pure limestone. There are five wells displaying pure limestone. Figure 3.2 displays the names and locations of these five wells. An example of pure limestone is shown in Figure 3.3 and Figure 3.4, which display the neutron-density crossplot, neutron-sonic crossplot, M-N plot and PEF plot of well FERRIS AND ST ORANGE NO 1 28. In Figure 3.3, in both the neutron-density crossplot and neutron-sonic crossplot, the data points are almost scattered on the limestone line. Gamma-ray values of most data points are less than $80 \mathrm{API}$. With the trend of increasing gamma-ray. There is no significant change on the neutron porosity, density and sonic. In Figure 3.4, both the M-N plot and PEF plot display the data points with very low gamma-ray readings, which are less than $30 \mathrm{API}$, and obviously focus on a limestone point. 


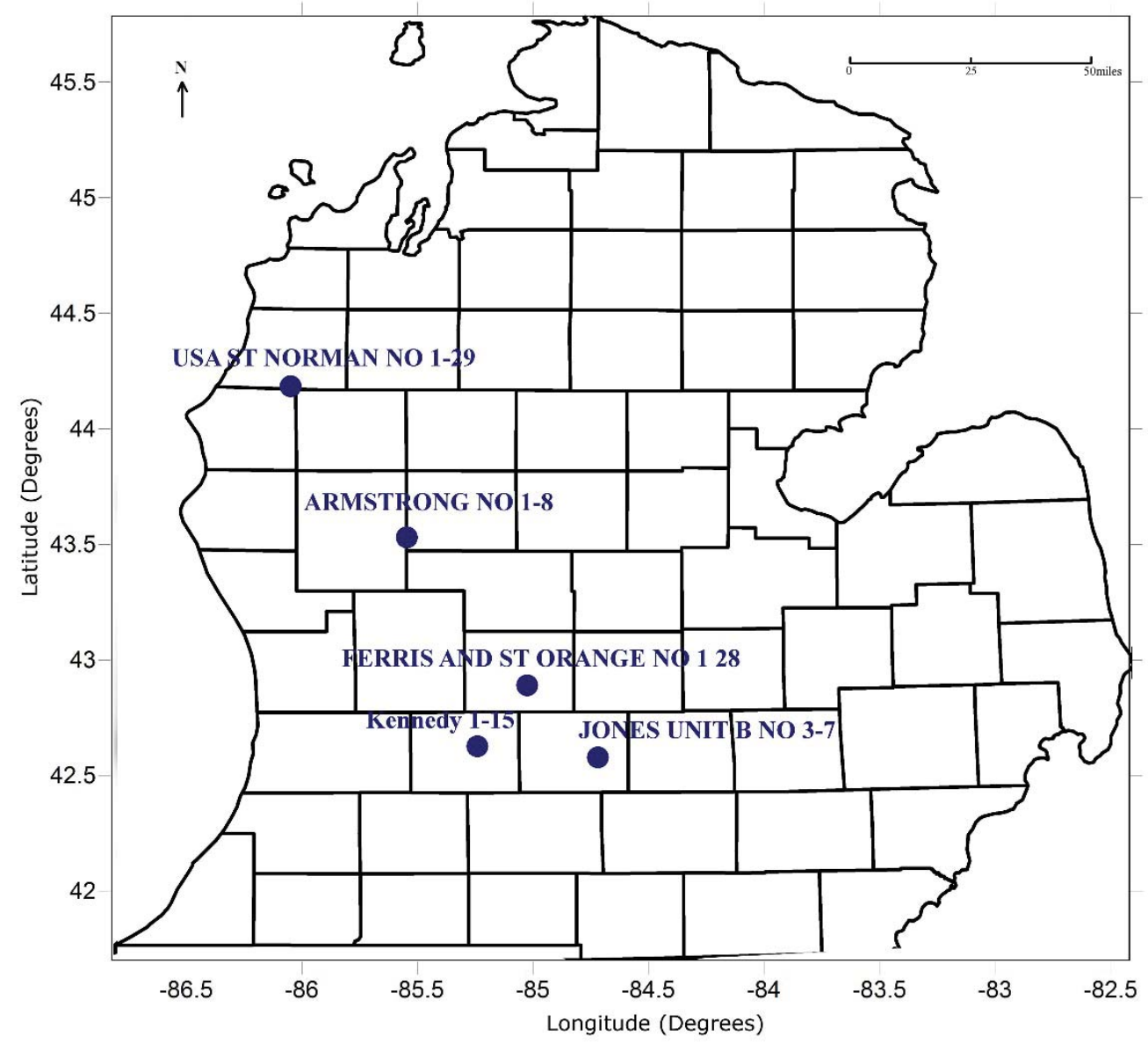

Figure 3.2 Names and locations of 5 wells with pure limestone. 


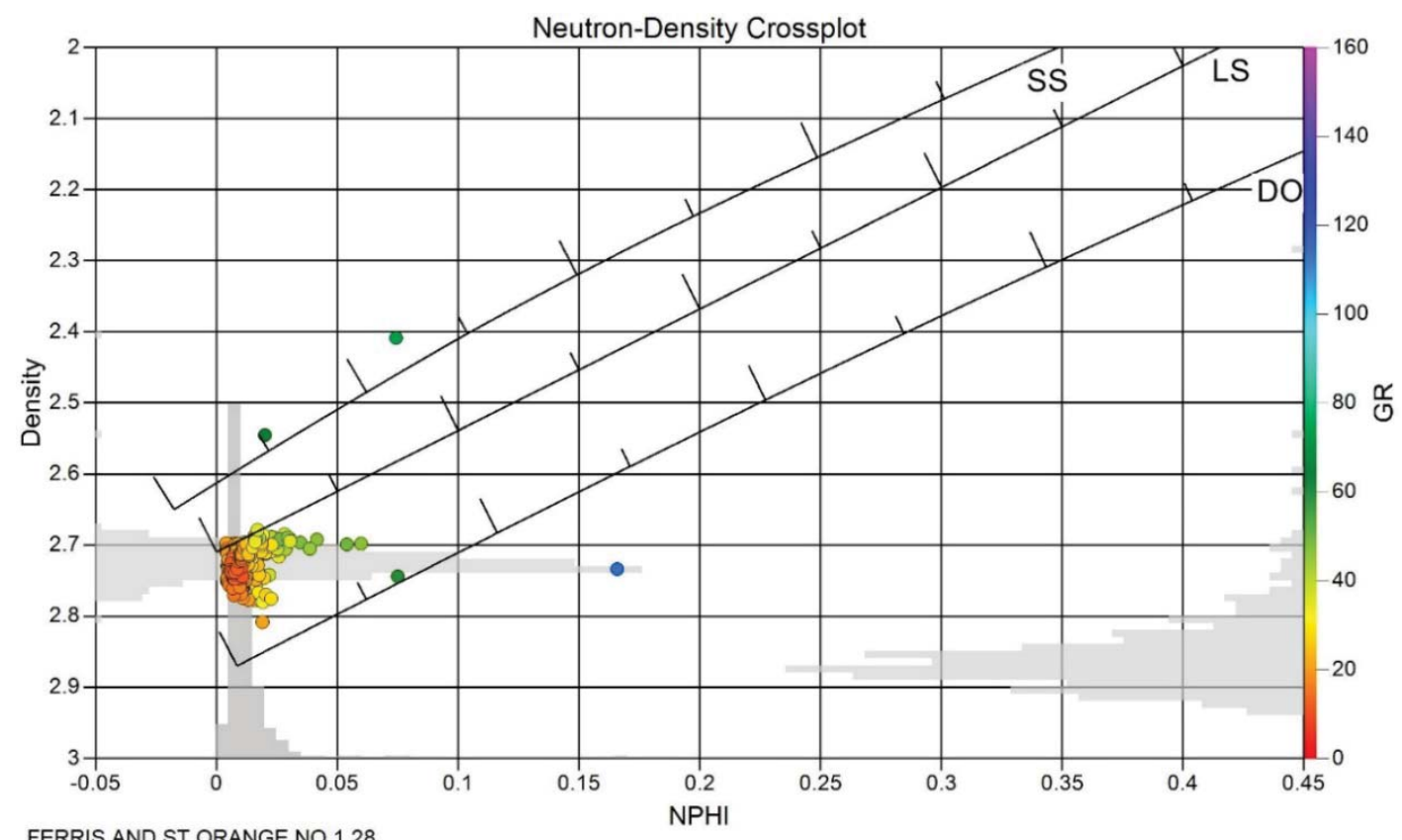

FERRIS AND ST ORANGE NO 128

Trenton Limestone(5723)-Black River Limestone(6080.5) 9/29/2014

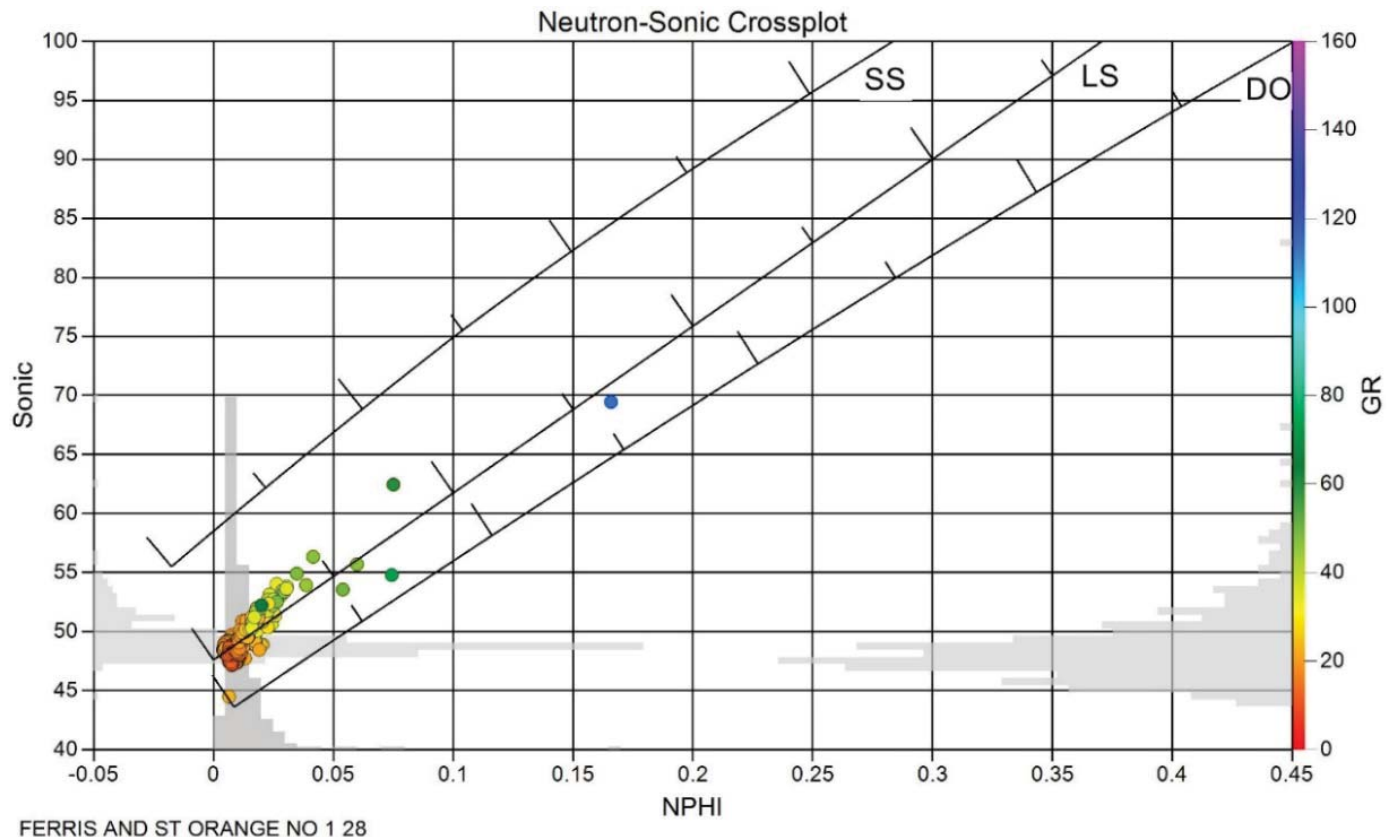

Trenton Limestone(5723)-Black River Limestone(6080.5)

9/29/2014

Figure 3.3 FERRIS AND ST ORANGE NO 128 (a) Neutron-density crossplot (b) Neutron-sonic crossplot. Data points fall on the limestone line, suggesting pure limestone with porosities ranging up to $5 \%$ or more. Color indicates gamma-ray response, showing mostly clean lithologies. 


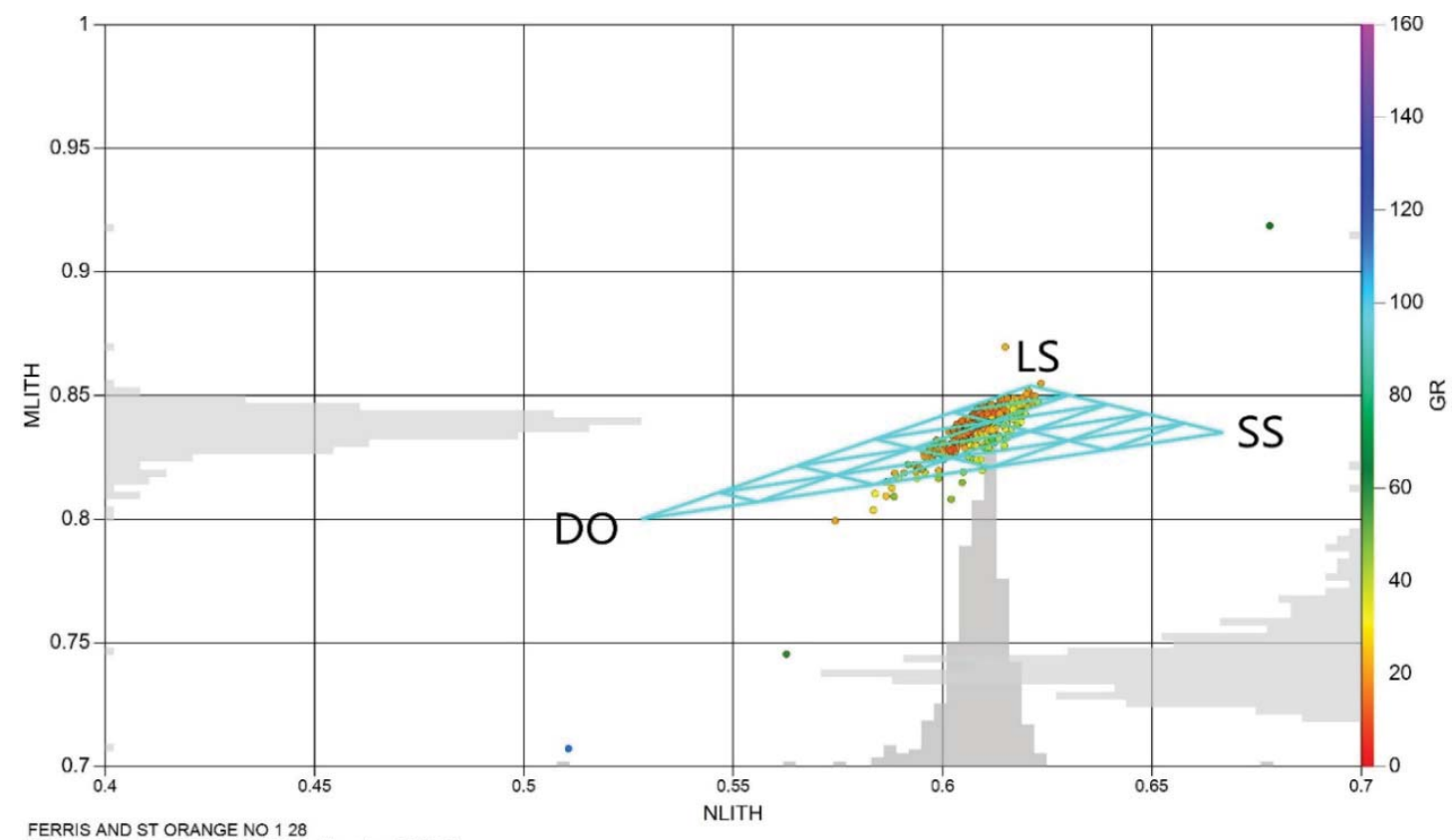

Trenton Limestone(5723)-Black River Limestone(6080.5) 9/29/2014

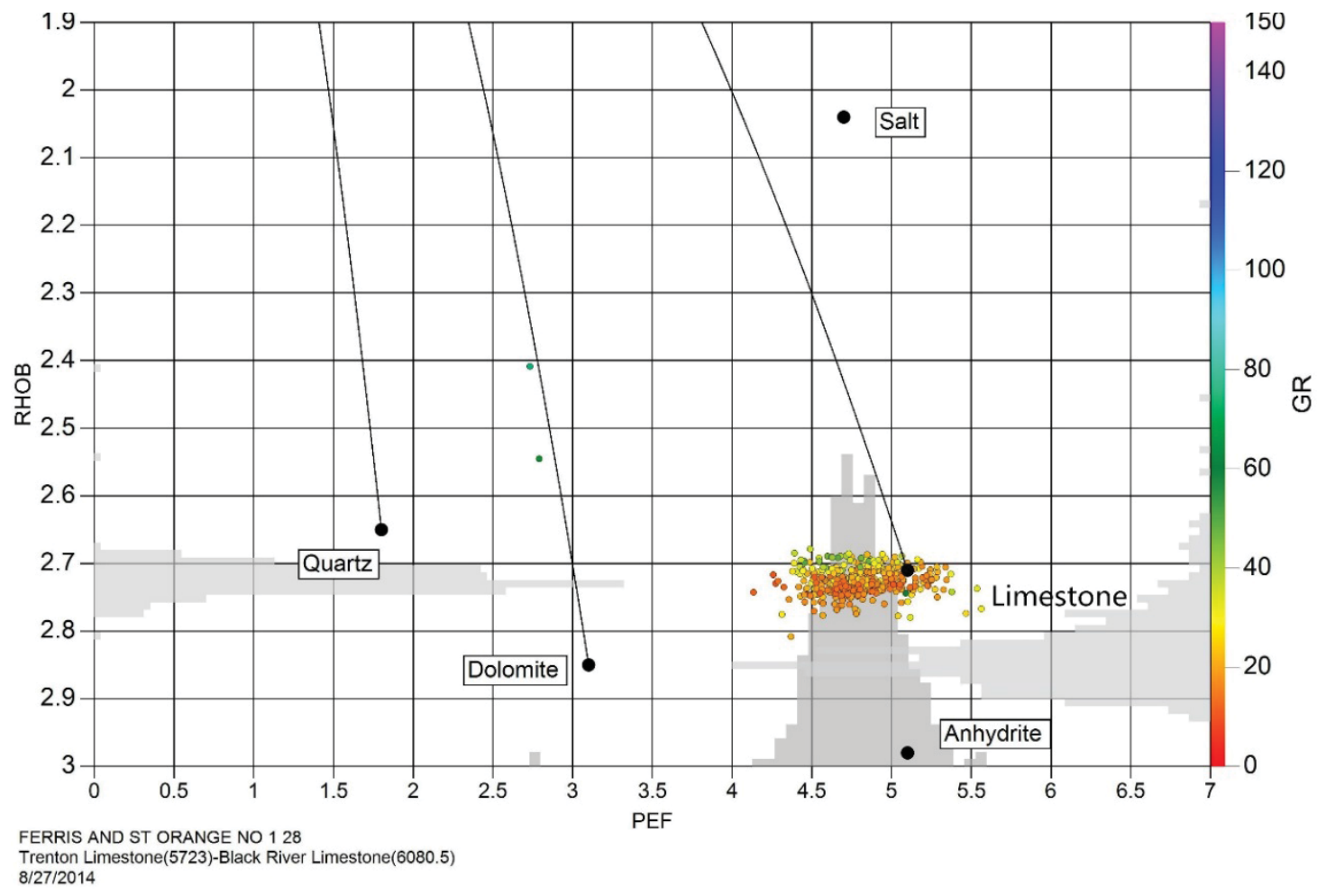

Figure 3.4 FERRIS AND ST ORANGE NO 128 (a) M-N plot (b) PEF plot. Data points mainly fall on the limestone point. Color indicates gamma-ray response, showing mostly clean lithologies. It indicates the primary mineral is limestone. 
Another class of results show partially dolomitized limestone. There are three wells displaying this type. Figure 3.5 displays the names and locations of the three wells. An example of dolomitized limestone in Figure 3.6 and Figure 3.7, which displays a neutrondensity crossplot, a neutron-sonic crossplot, an M-N plot and a PEF plot of well BONINE NO 1-22. In Figure 3.6, we see that with the increasing gamma-ray, neutron porosity also increases, but the sonic and density log barely changes. This can be explained by secondary porosity. Secondary porosity in carbonates is frequently caused by dolomitization. When water carrying magnesium passes through limestone, calcite crystals will change to dolomite, as some calcium (providing the calcite in limestone) is replaced by magnesium (yielding dolomite). The newly formed dolomite has a smaller volume (higher density) than the original mineral, so new porosity had to be added to the existing calcite porosity, which is often present in the form of fractures. Dolomite has a higher matrix sonic velocity than limestone, but due to the fractures, a higher porosity. As a matrix changes from limestone to dolomite, the bulk density effects of increased porosity and dolomitization may cancel each other out. Moreover, sonic logs only respond to primary porosity, ignoring vuggy porosity and fractures, neutron log responds to the total porosity, whether large or small, primary or secondary. So the sonic log exhibits little variation while the neutron porosity increases. In Figure 3.7, most data points with low gamma-ray distribute between the limestone and dolomite points, indicating varying dolomitization among the clean (nonshaly) formations. 


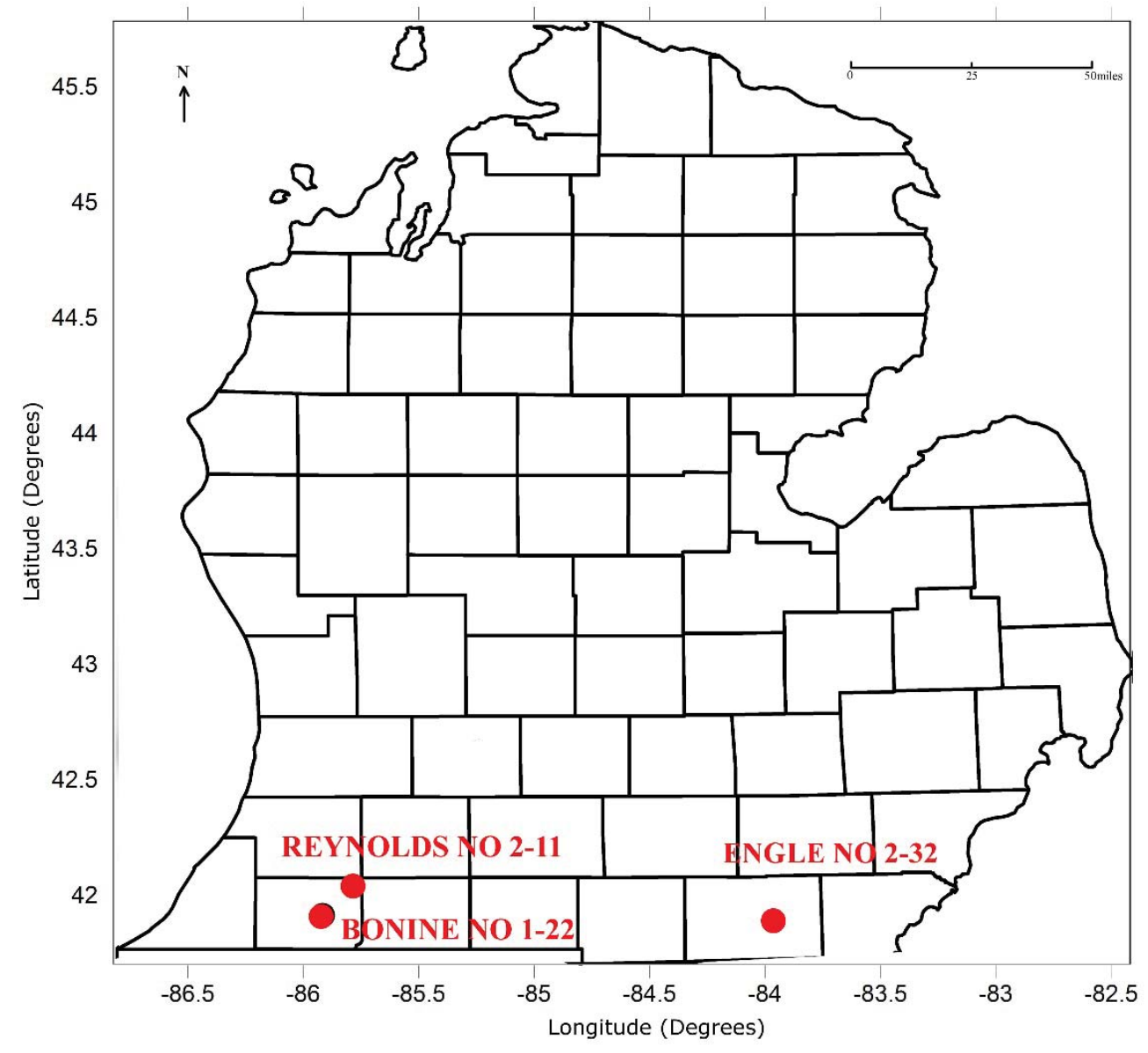

Figure 3.5 Names and locations of 3 wells with partially dolomitized limestone. 


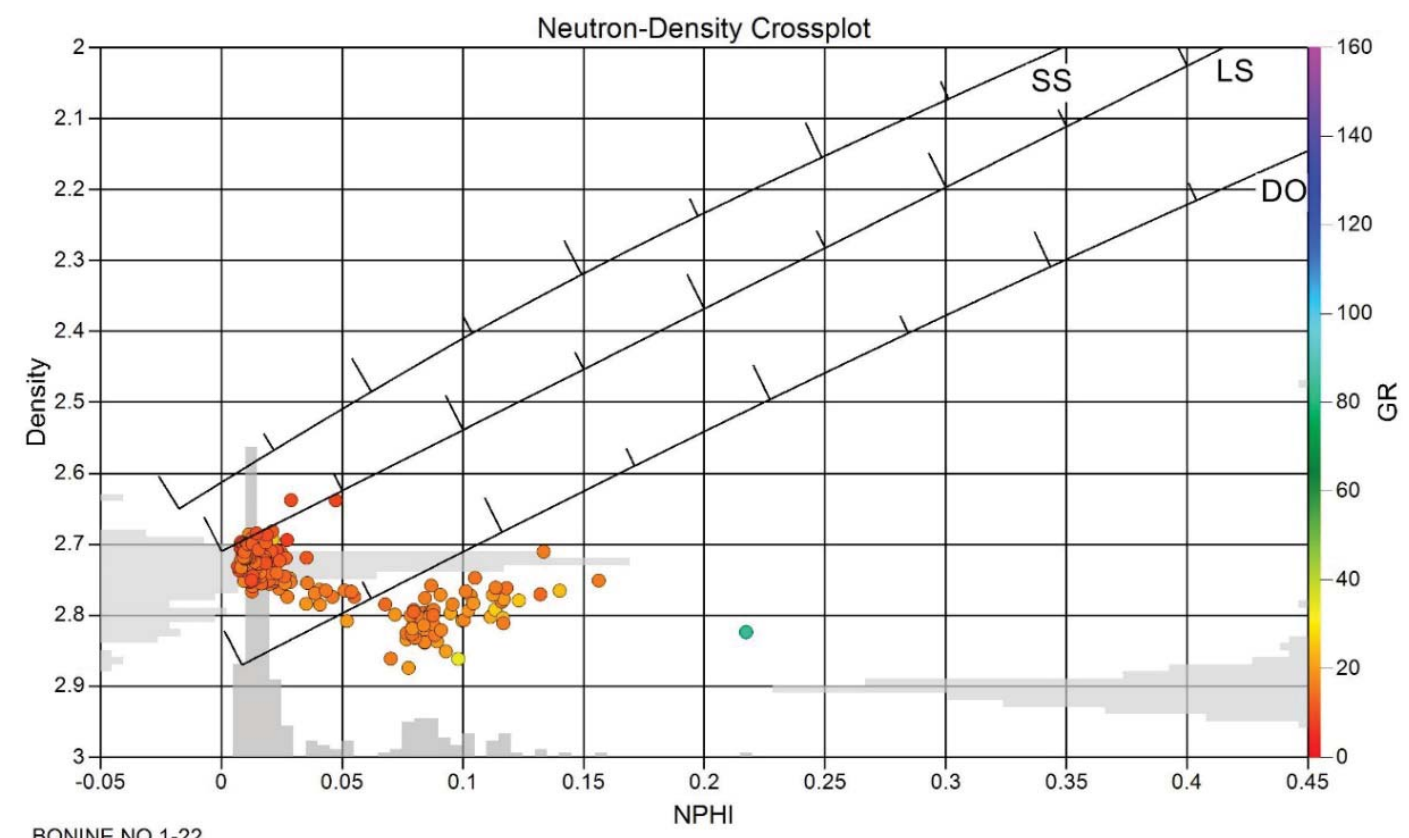

BONINE NO 1-22

Trenton Limestone(2327.5)-Black River Limestone(2589.5) 9/29/2014

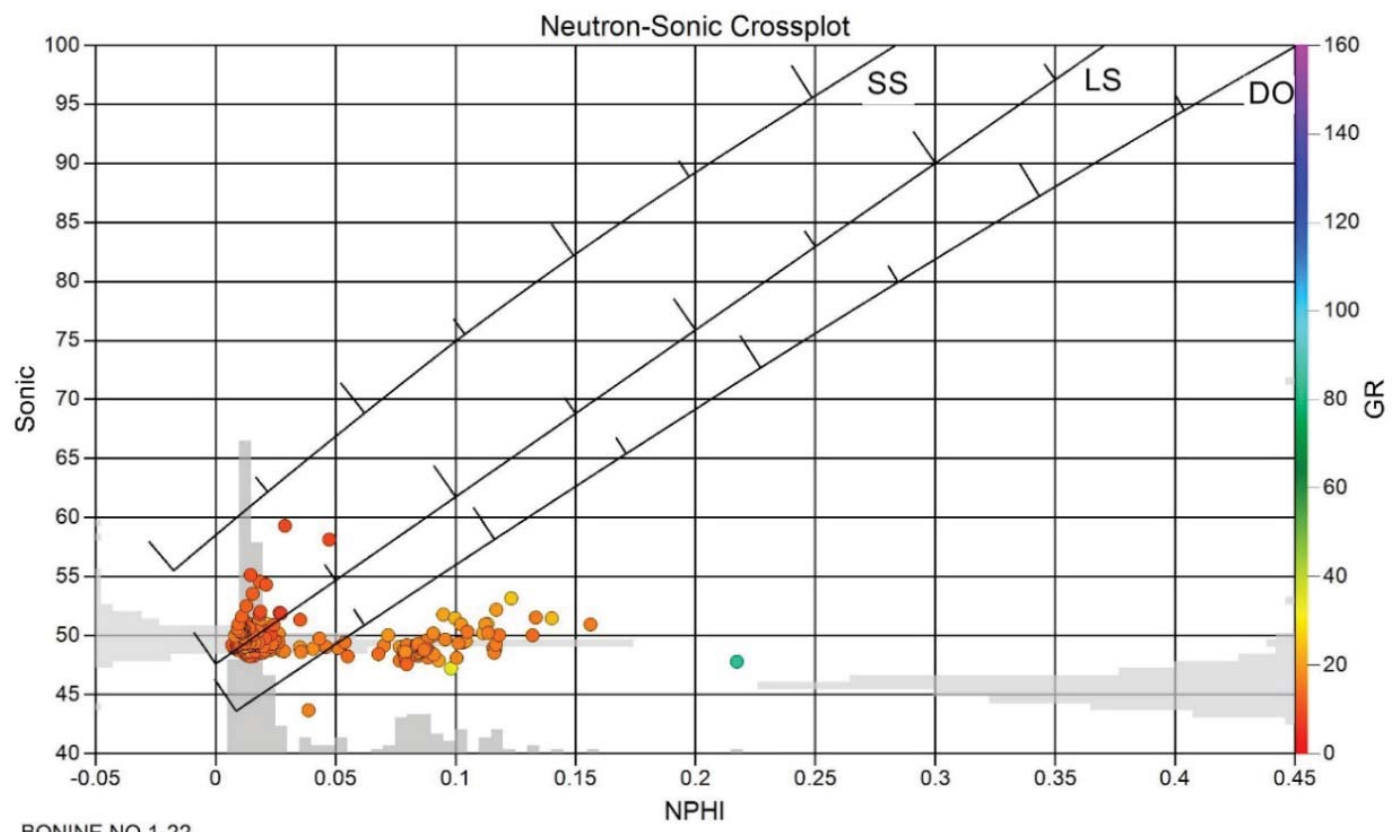

BONINE NO 1-22

Trenton Limestone(2327.5)-Black River Limestone(2589.5) 9/29/2014

Figure 3.6 BONINE NO 1-22 (a) Neutron-density crossplot (b) Neutron-sonic crossplot. With the increasing gamma-ray, neutron porosity increases, but the density and sonic log change little. The distribution of data points can be due to the effect of the secondary porosity. Color indicates gamma-ray responses, which are almost less than 30 API. 


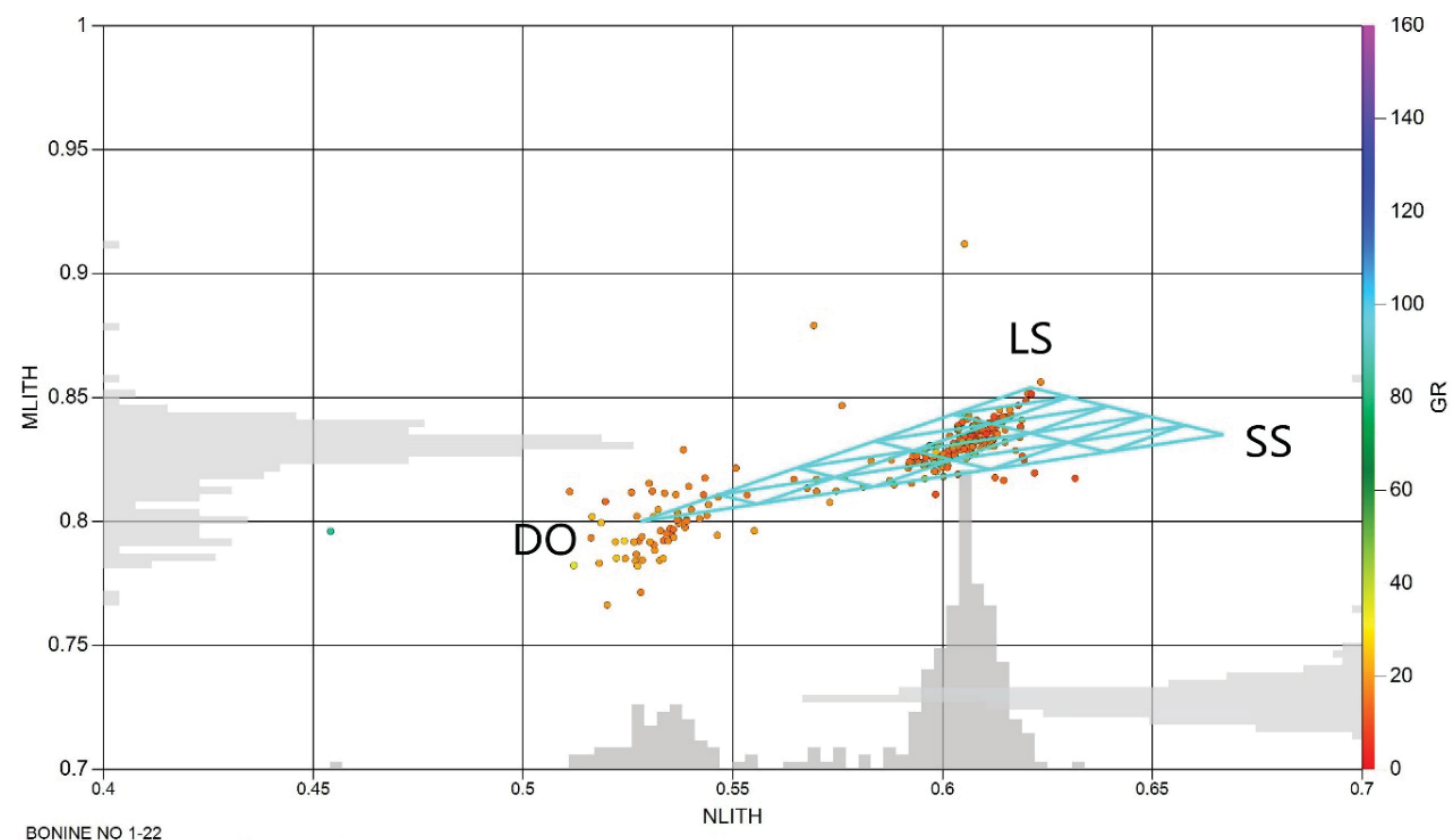

BONINE NO 1-22

Trenton Limestone(2327.5)-Black River Limestone(2589.5) 9/29/2014

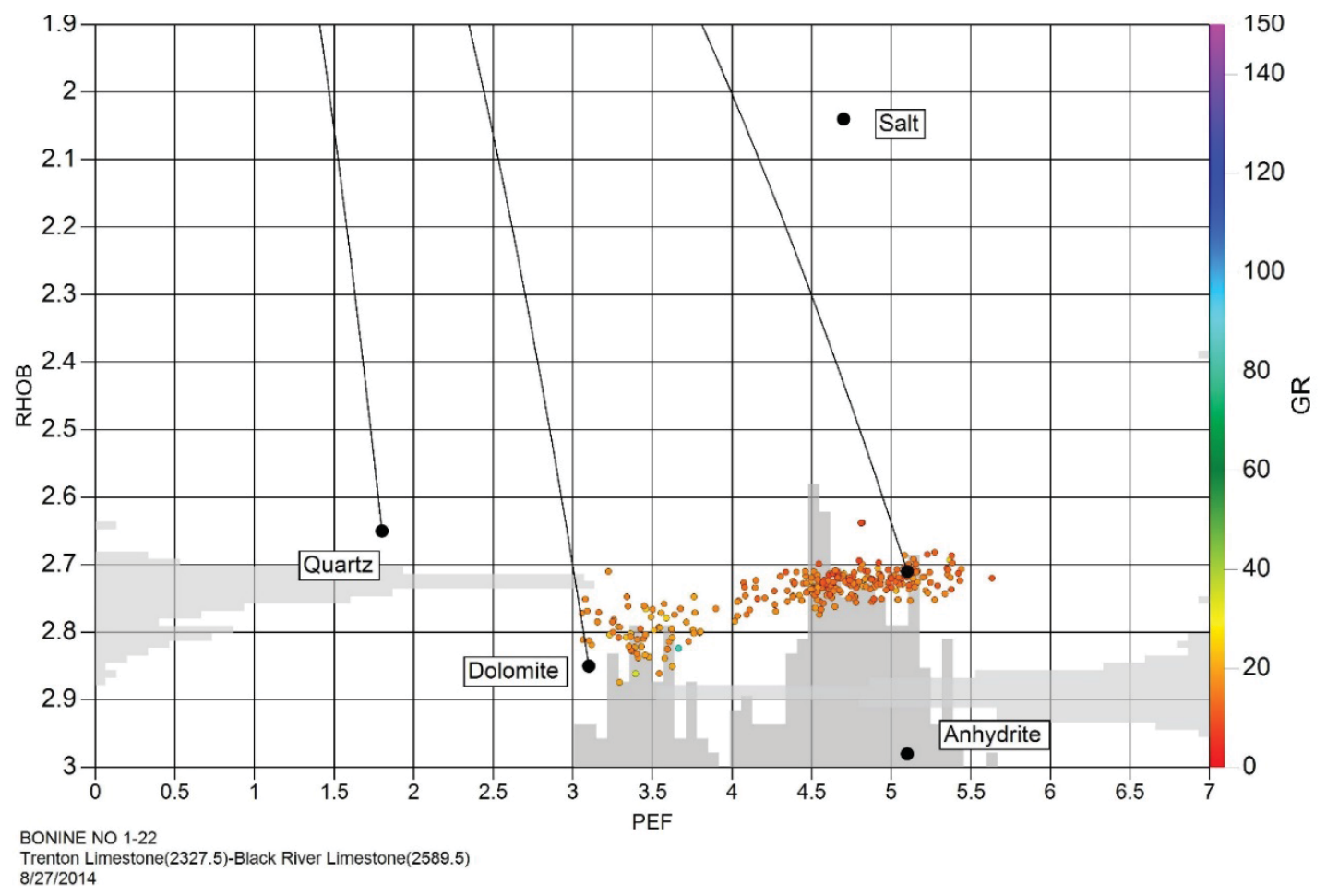

Figure 3.7 BONINE 1-22 (a) M-N plot (b) PEF plot. Data points fall on limestone and dolomite points. Color indicates gamma-ray responses, which are less than 30 API. The distribution of data points is affected by the secondary porosity. 
The last type of lithology encountered in the Trenton-Black River formation is shaly limestone. There are eighteen wells classified as exhibiting shaly limestone in this study. Figure 3.8 displays the names and locations of the eighteen wells. An example of shaly limestone in Figure 3.9 and Figure 3.10, which displays the neutron-density crossplot, the neutron-sonic crossplot, the M-N plot and the MID plot of well HAROUTUNIAN UNIT NO 14 . In Figure 3.9, both the neutron-density crossplot and the neutron-sonic crossplot show an increase in gamma-ray up to $60 \mathrm{API}$, and the higher gamma-ray points move towards the clay points on these plots.

The distribution of data points in the M-N plot and the MID plot may display different shifts depending on the lithologies involved. The direction of shifts are caused by shaliness, secondary porosity or the presence of gas. A greater concentration of shale shifts the points downward outside the (quartz-dolomite-calcite or sandstone-dolomite-limestone) triangle in the M-N plot, and above or to the right of the anhydrite point in the MID plot. Secondary porosity shifts the points up in the M-N plot, and decreases the apparent matrix transit time in the MID plot. Gas tends to shift points upward and to the right on both the M-N plot and the MID plot. Additional mineral constituents, other than the three primary (quartz, dolomite, calcite) minerals considered, may cause the data points to plot outside the triangle in the M-N or MID plots (Schlumberger 1991). In Figure 3.10, the arrow in the M-N plot shows that data points in this well fall below the triangle in the M-N plot. The gamma-ray values of the points in this direction are higher than those within the triangle, and one can conclude that the shift is caused by the presence of clay minerals in shale. In the MID plot, as the presence of shale can decrease the velocity which increases the transit time, the arrow shows the direction of shift to the right. With increasing apparent matrix transit time and gamma-ray, points in this direction are also above the anhydrite point. Both of the shifts in the two plots can demonstrate the presence of shale in well HAROUTUNIAN UNIT NO 14. 


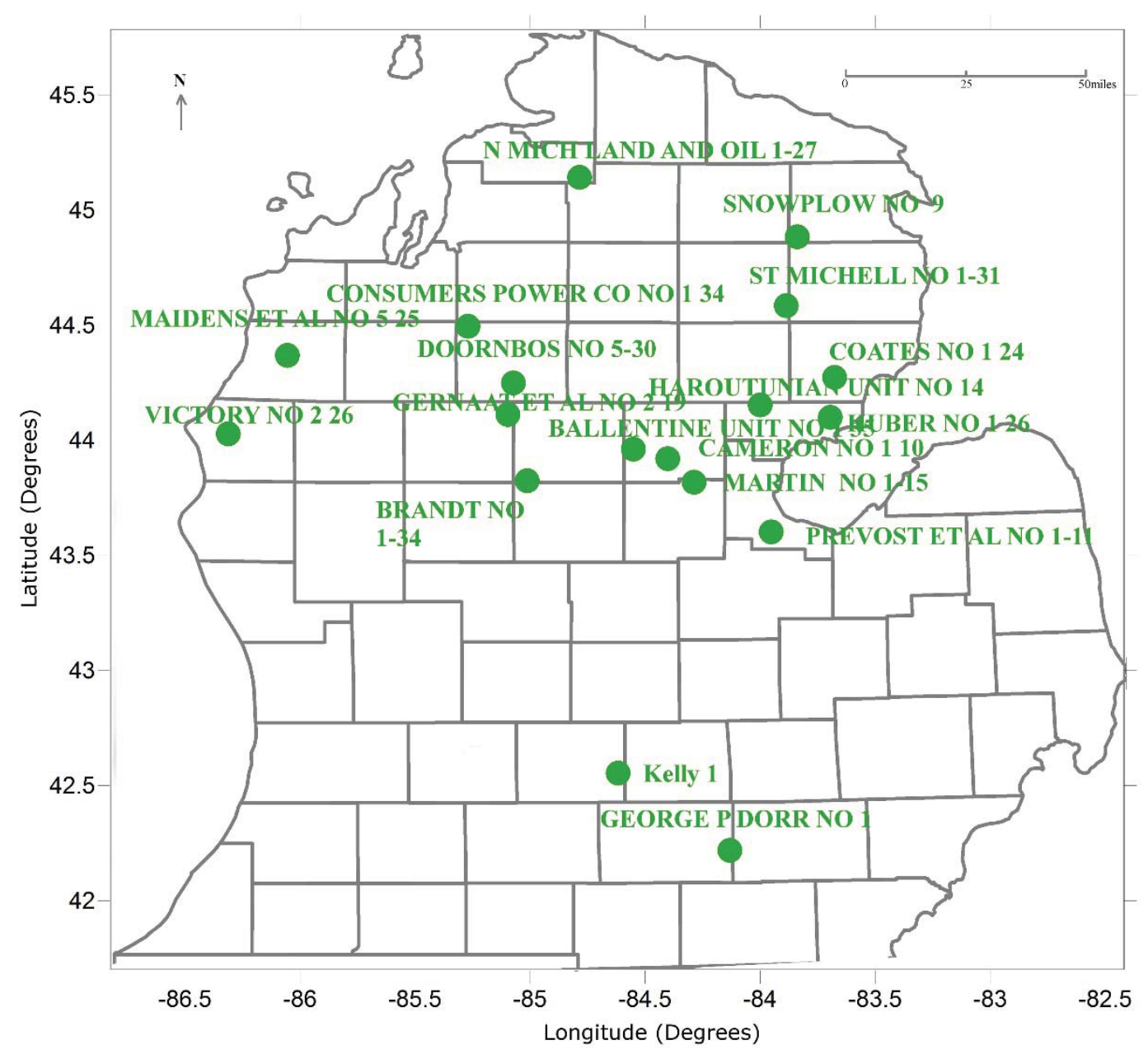

Figure 3.8 Names and locations of 18 wells with shaly limestone. 


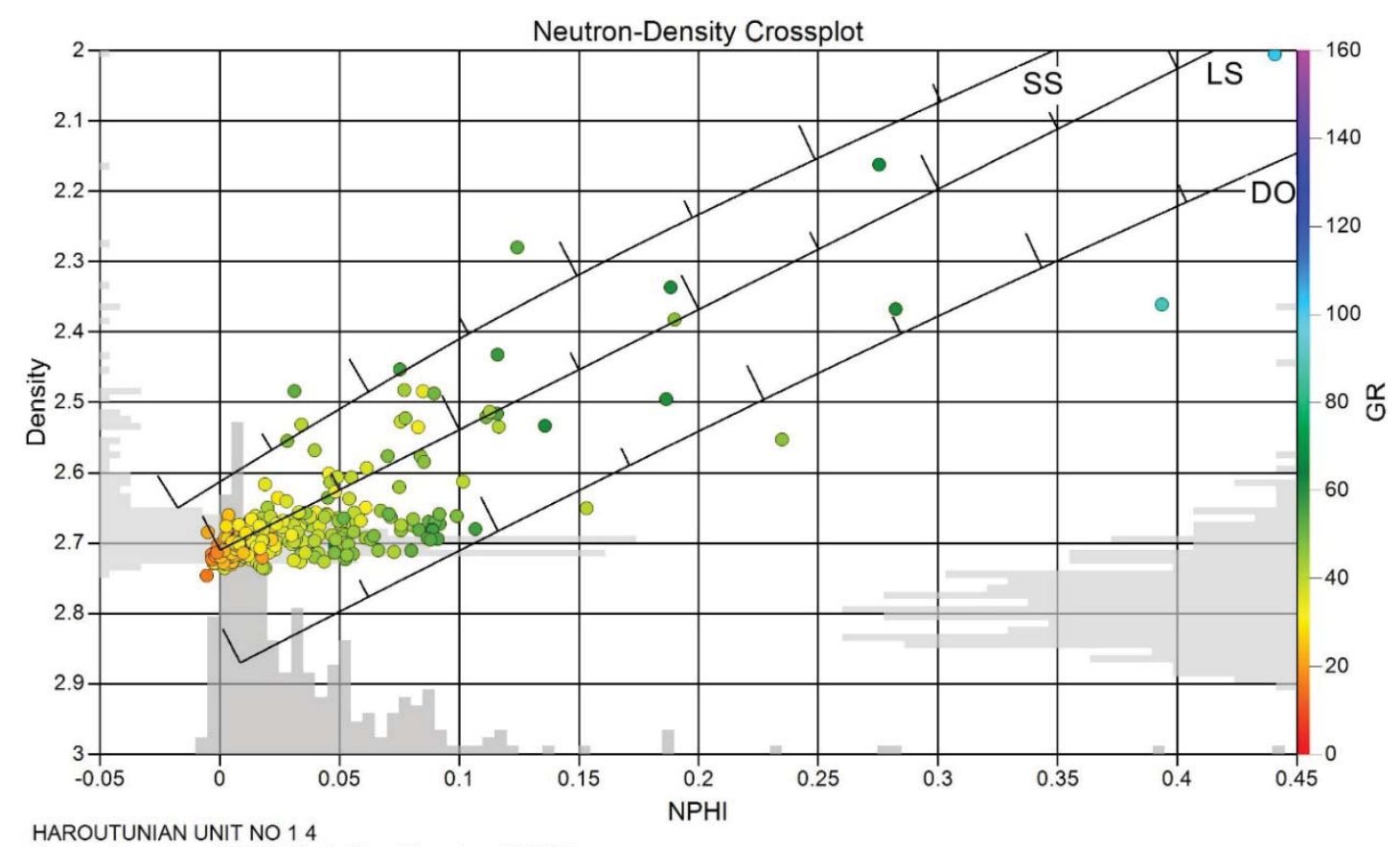

HAROUTUNIAN UNIT NO 14

Trenton Limestone(9774)-Black River Limestone(10063)

9/29/2014

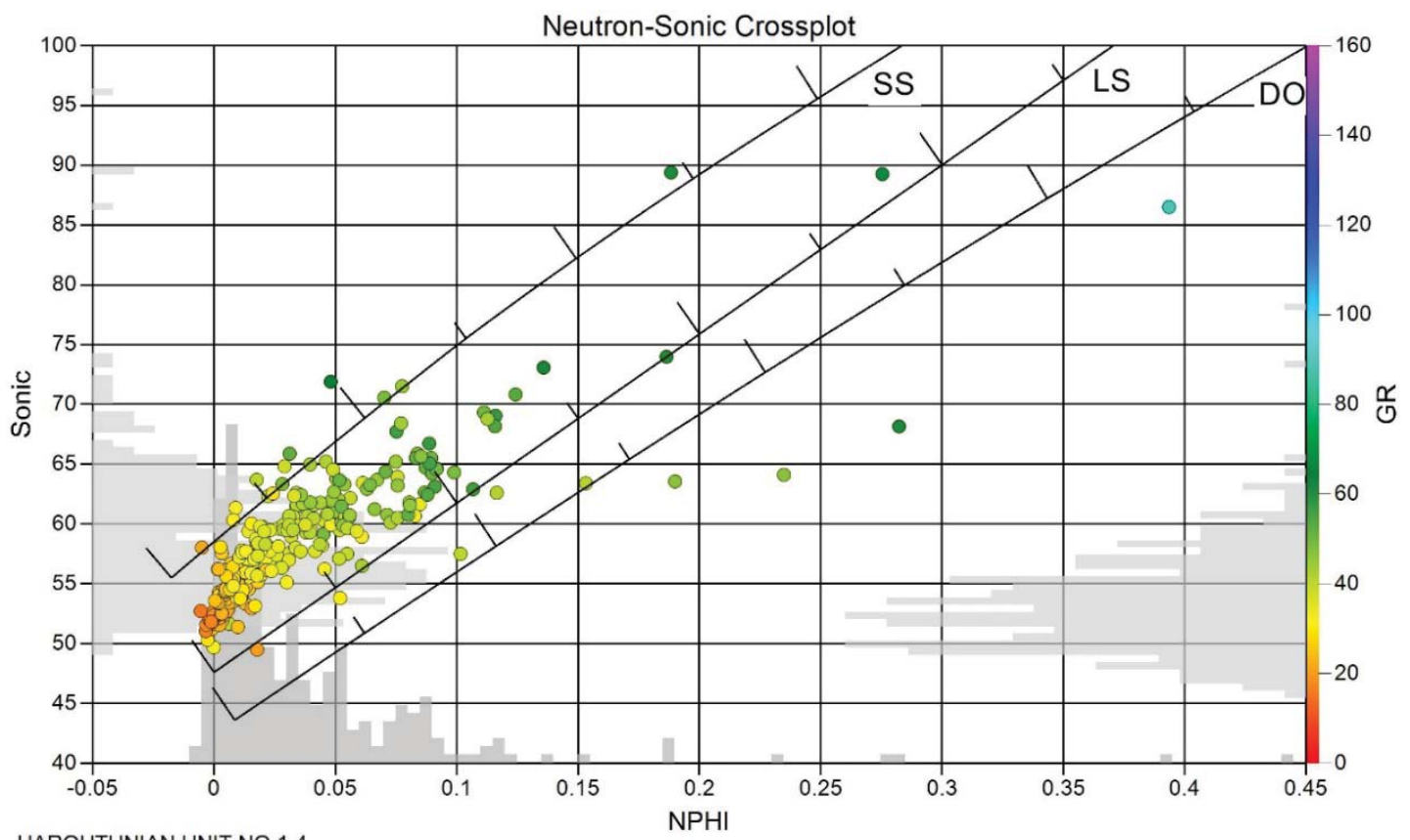

HAROUTUNIAN UNIT NO 14

Trenton Limestone(9774)-Black River Limestone(10063)

9/29/2014

Figure 3.9 HAROUTUNIAN UNIT NO 14 (a) Neutron-density crossplot (b) Neutronsonic crossplot. Data points fall on the limestone line. Color indicates gamma-ray responses, which show the tendency of data points to move towards clay points. 


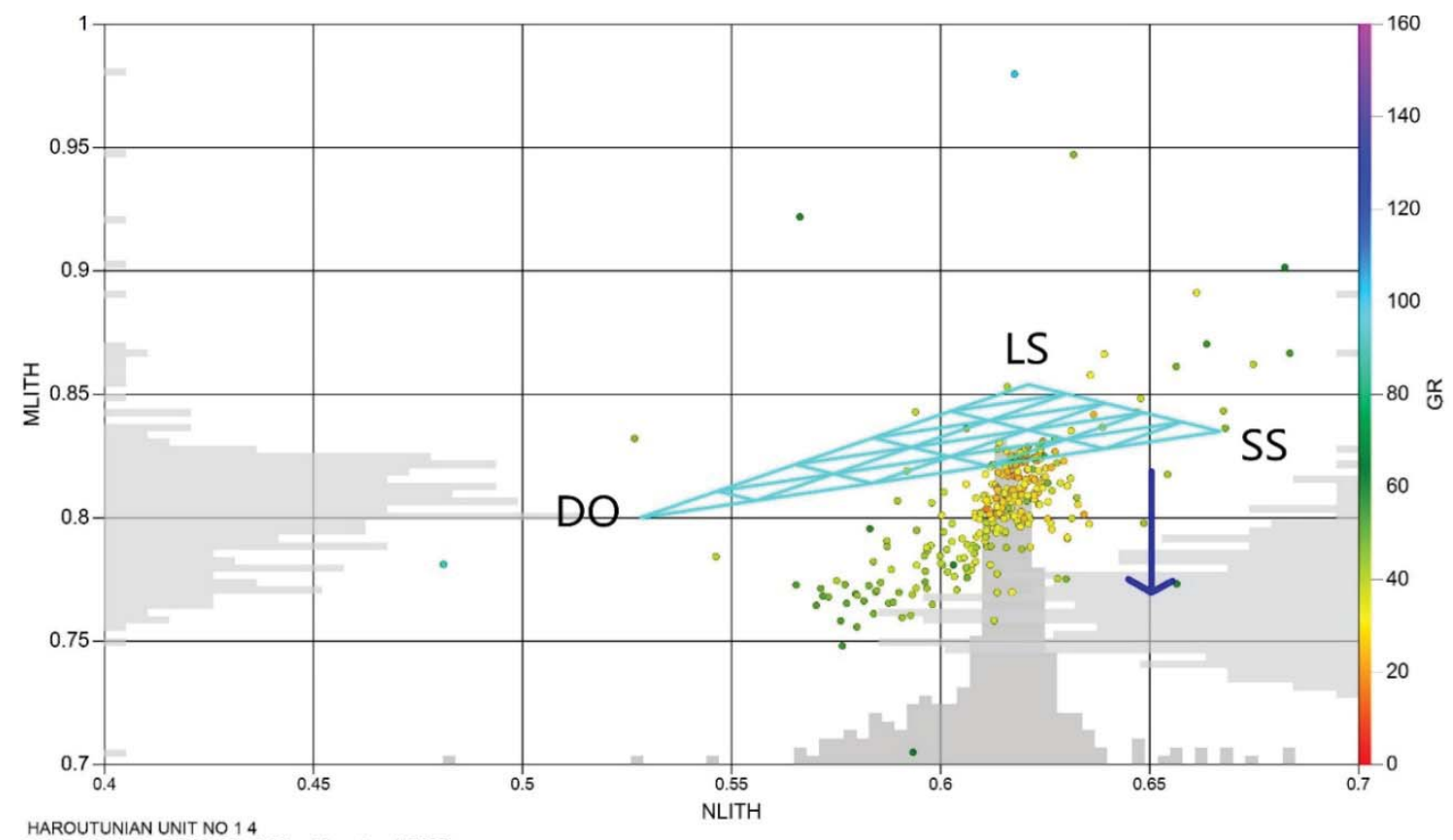

Trenton Limestone(9774)-Black River Limestone(10063) 9/29/2014

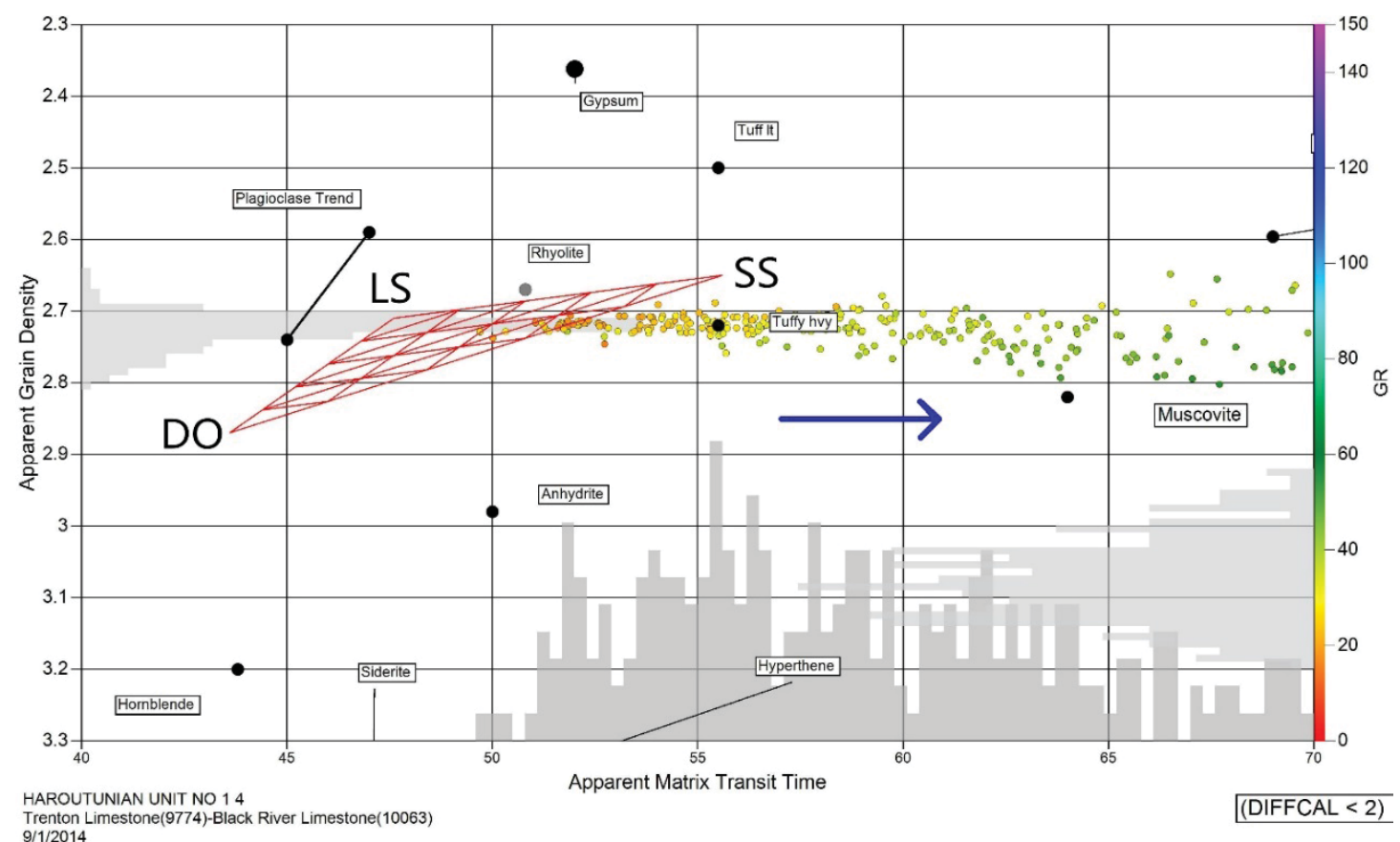

Trenton Limestone(9774)-Black River Limestone(10063)

$($ DIFFCAL <2)

Figure 3.10 HAROUTUNIAN UNIT NO 14 (a) M-N plot (b) MID plot. Data points demonstrate the presence of shale. 
In a summary of the observations made above, Figure 3.11 displays the names and locations of all the twenty-six wells used for the crossplot evaluations. Blue points are the five wells with pure limestone, red points are the three wells with partially dolomitized limestone, and green points are the eighteen wells with shaly limestone. From their distribution, we can see that most wells with shaly limestone fall on the north central part of the basin. In general, these results compare favorably with those obtained from the modified mineral identification technique (described in the following section) which led to the contour maps of dolomitization in Figure 2.2 and shale fraction in Figure 2.3.

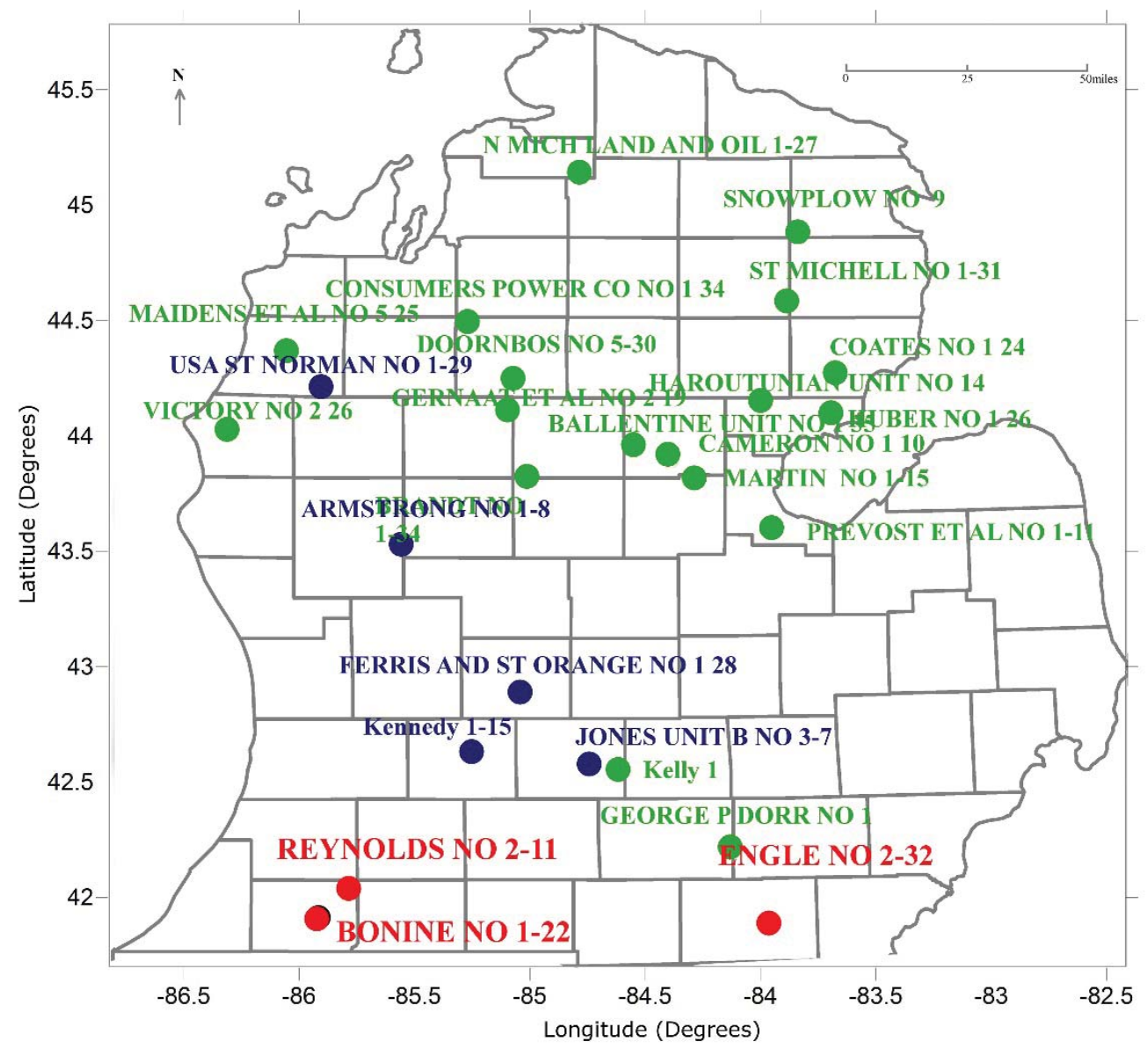

Figure 3.11 Names and locations of twenty-six wells used in crossplots. Blue points are the five wells with pure limestone, red points are the three wells with partially dolomitized limestone, and green points are the eighteen wells with shaly limestone. 
With the combination of gamma-ray, the bulk density log, the PEF log and the neutron porosity log, a modified mineral identification technique used by Islam (2011) can determine the four mineral components and each fraction, including quartz, calcite, dolomite and clay. Conventional three-mineral and four-mineral identification approaches are modified by first removing the shale effect from all the logs (Islam 2011). In the 3mineral identification approach, gamma-ray response is often neglected, as the data analysis is only on the basis of dry grain density (DGA) and apparent matrix volumetric cross section (UMA) responses, sometimes limestone and clay may be replaced by dolomite. In the 4-mineral identification approach, shale volume is changed to balance the dry grain density (DGA) and apparent matrix volumetric cross section (UMA) responses, so the mineral calculation would be less accurate. In order to correct the two problems, in the modified mineral identification approach, the shale volume determined from gammaray response was fixed by removing the shale effect from all the logs in the four-mineral identification approach, including density log, porosity log and PEF log. Then apply the corrected value with assuming linear law of volumetric mixing to the three-mineral identification approach. (Islam 2011). All the equations, parameters and code details are explained in Appendix I. Because some wells do not have a PEF log, this method was applied to twenty-six wells.

I obtained a good estimate of each mineral component and displayed the results as a lithology track in a log plot. I divided the results into three types. Most wells exhibit limestone with a little amount of dolomite, sandstone and clay. Two wells are identified as mostly limestone with a large amount of dolomite, and five wells show nearly pure limestone in this formation. This approach uses DGA and UMA, which are the same factors involved in @maa vs. $U_{\text {maa }}$ MID plot. Through a comparison of the lithology display with the Qmaa vs. Umaa MID plot, one can conclude that the modified mineral identification approach yields results very similar to that from the crossplotting techniques. For example, Figure 3.12(a) displays the Qmaa vs. $\mathrm{U}_{\text {maa }}$ MID plot of well VICTORY NO 2 26, indicating a large amount of limestone and dolomite in Trenton-Black River limestone, while 3.12(b) displays a lithology track showing the results from the modified mineral identification method with similar results. The results from the modified mineral identification approach 
were summarized in Figures 2.2 and 2.3, and are similar to those obtained from the crossplotting techniques, summarized in Figure 3.11, except three wells: Kelly 1, George P DORR NO 1, and ENGLE NO 2-32. The three wells tend to be shaly shale and partially dolomitized limestone, but they show less fractions on contour maps, which can be explained by that the shale content and limestone content are less in the three wells, but they do have the tendency to display characteristics of shaly shale and partially dolomitized limestone.

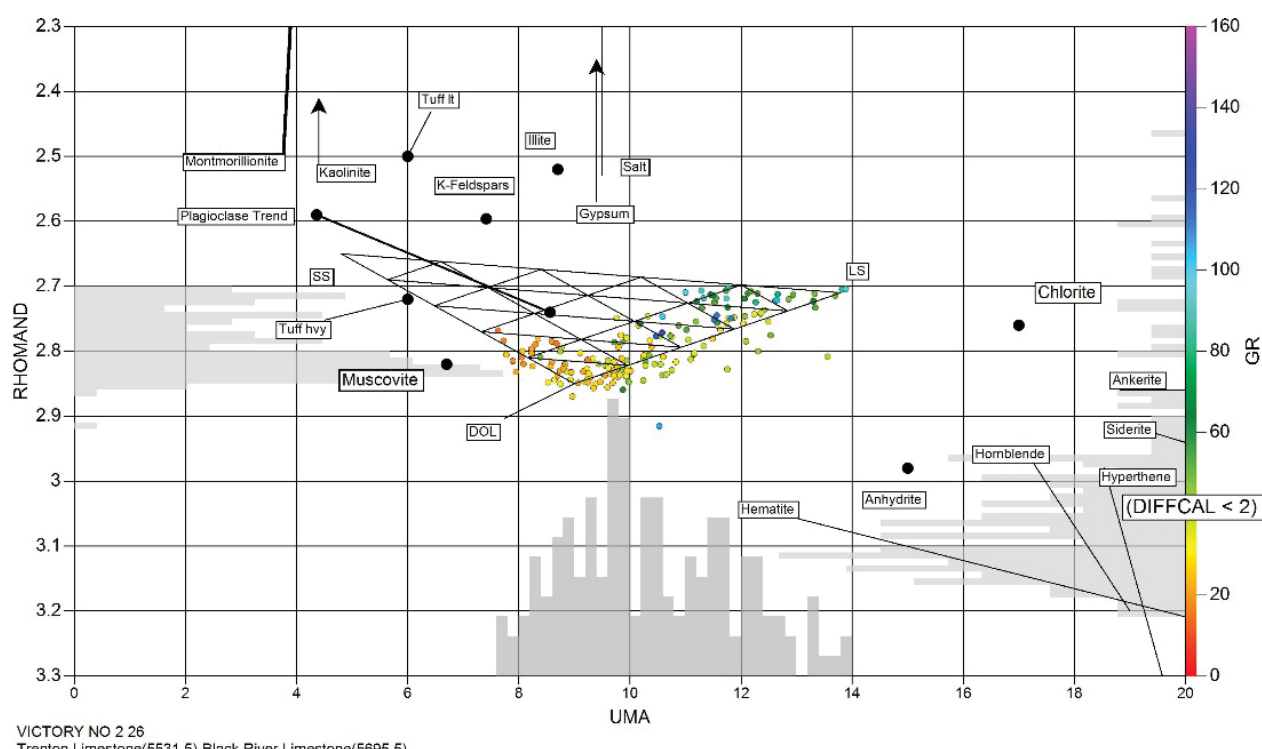

VICTORY NO 22 Trenton Limestone(5531.5)-Black River Limestone(5695.5)
10/14/2014

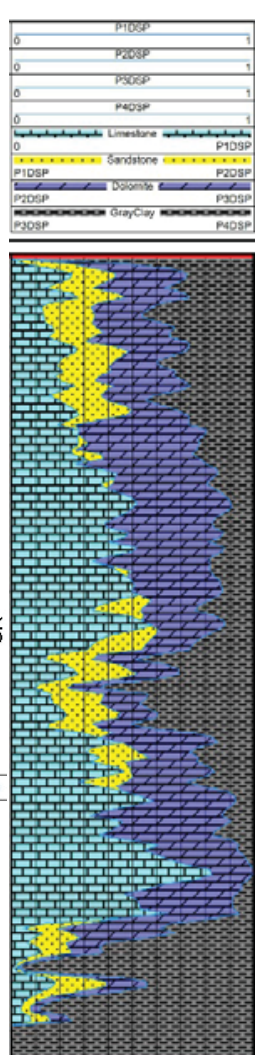

(b)

Figure 3.12 (a) Qmaa vs. Umaa MID plot of well VICTORY NO 226 with Trenton-Black River limestone, indicating the presence of limestone and dolomite; (b) Lithology display of well VICTORY NO 226 with Trenton-Black River limestone, indicating the presence of limestone, dolomite, little sandstone and clay. Green is limestone, yellow is sandstone, purple is dolomite and grey is clay. 


\section{Thomas Stieber Method}

One reason for initiating this study was to investigate the possibility of using a technique commonly applied in clastic rocks for the study of clay distribution to the carbonates of the Trenton-Black River formation, which is a new attempt. The Thomas Stieber method is frequently used to distinguish shale types in sandstone using the density and gamma-ray logs to differentiate three ways that shale can be distributed in sand: dispersed, laminated and structural. Figure 4.1 graphically depicts these types. Dispersed shale accumulates to the grains of the sandstone, and can decrease effective porosity, permeability and fluid mobility, but because of the water content of clays it can increase measured water saturation. Almost all sandstones contain some dispersed shale. Laminated shale exists as fine layers in the rock; because the effective porosity and permeability of shale are zero, laminated shale can decrease the overall porosity and permeability, but has no influence on these properties within each individual thin sand bed. Structural shale takes the place of sand grains, and can be considered as part of the rock framework; it has no effect on porosity and permeability, but it does not occur frequently.
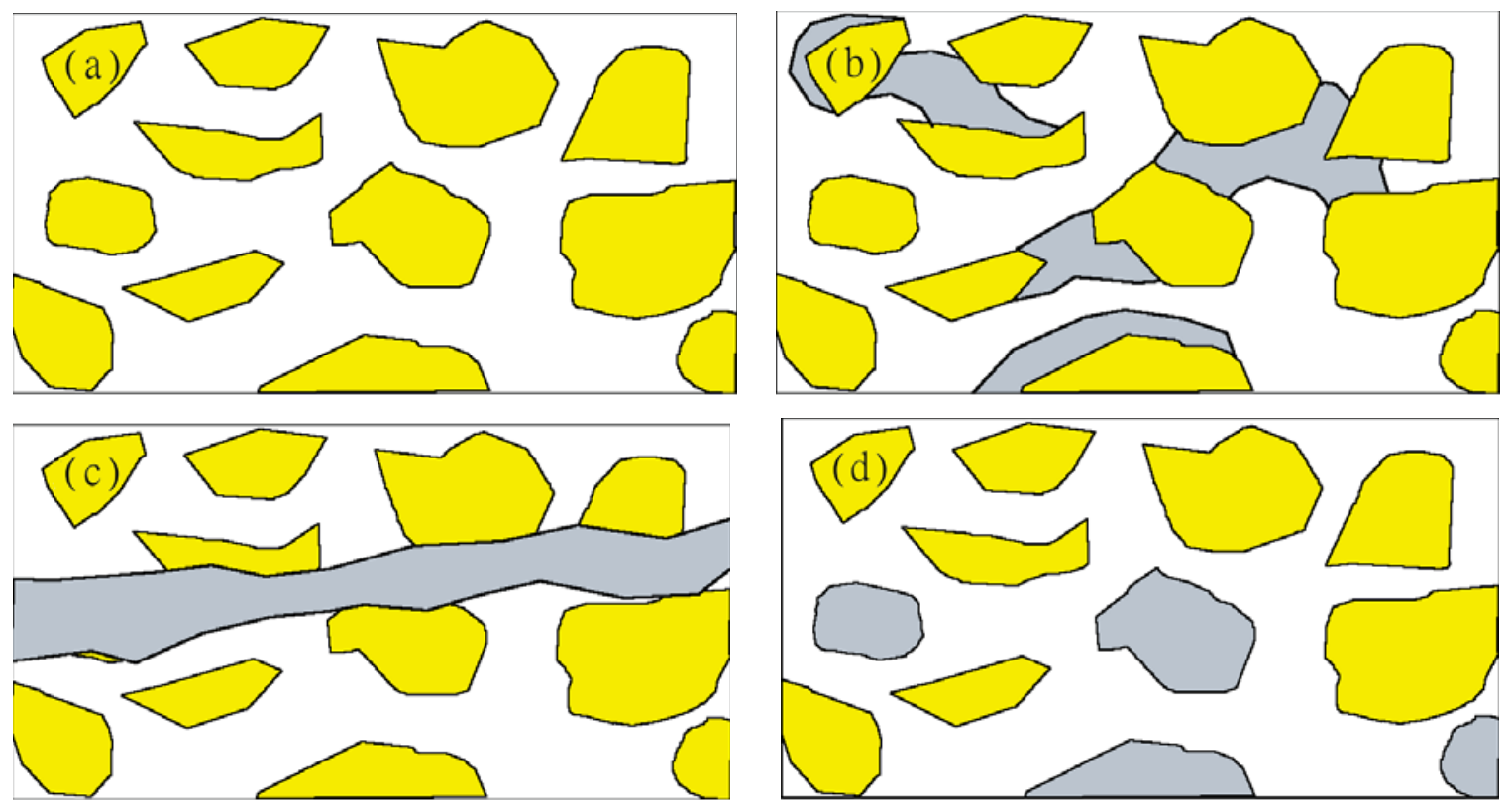

Figure 4.1 Clean sand and three shale types in sandstone. Yellow parts are sand grains, grey parts are shale. (a) Clean sand; (b) Dispersed shale in sand, accumulates to the grains; 
(c) Laminated shale in sand, existing as layers; (d) Structural shale in sand replaces the sand grains.

Before introducing this method, an explanation of the assumptions is necessary. (1) We assume that shale is the only factor that destroys porosity. (2) We consider the two endmembers of shaly sand to be clean sand and pure shale. (3) Because the gamma-ray log response is sensitive to mass of radioactive grains, this method works best when the shale and sand have similar grain density.

When dispersed shale is in the pore space, I imagine that one end-member is clean sand and that dispersed shale is added into the pore space incrementally. The amount of dispersed shale that can be added is limited due to the pore volume (because dispersed shale does not displace sand), so the maximum volume of dispersed shale is the original porosity of clean sand. After all the pore space is filled with shale, the resulting porosity is at a minimum. For laminated shale, two end-members are clean sand and pure shale because laminated shale both occupies pore space and replaces sand grains. The porosity and gamma-ray values both vary linearly between the two end-members. On the other hand, structural shale only replaces sand grains. As the porosity of solid sand grains is zero, replacing it with shale can increase both gamma-ray values and porosity. It is useful to normalize all the gamma-ray responses by finding gamma-ray values of clean sand and pure shale.

Figure 4.2 shows an example of a Thomas Stieber template for sandstone with one data point. That data point represents a shaly sand with normalized gamma-ray log value of 0.38 and density porosity of 0.22 . To normalize the values, I used gamma-ray values for clean sand and pure shale of 15 API and 100 API and density porosities of clean sand and pure shale of 0.3 and 0.1. Equations and parameters for each type of shale are in Appendix II. The lines in Figure 4.2, are drawn such that a triangle is formed by the three lines of dispersed shale, laminated shale and dispersed-to-structural shale. I also created some additional dispersed-shale lines by increasing the content of laminated shale by $10 \%$ for each line. The location of a data point in this plot can distinguish the associated shale type 
and its fraction. Take an example of the small yellow triangle in Figure 4.2. The normalized gamma-ray value is 0.4 and the density porosity is 0.21 , and the laminated shale content is $38 \%$.

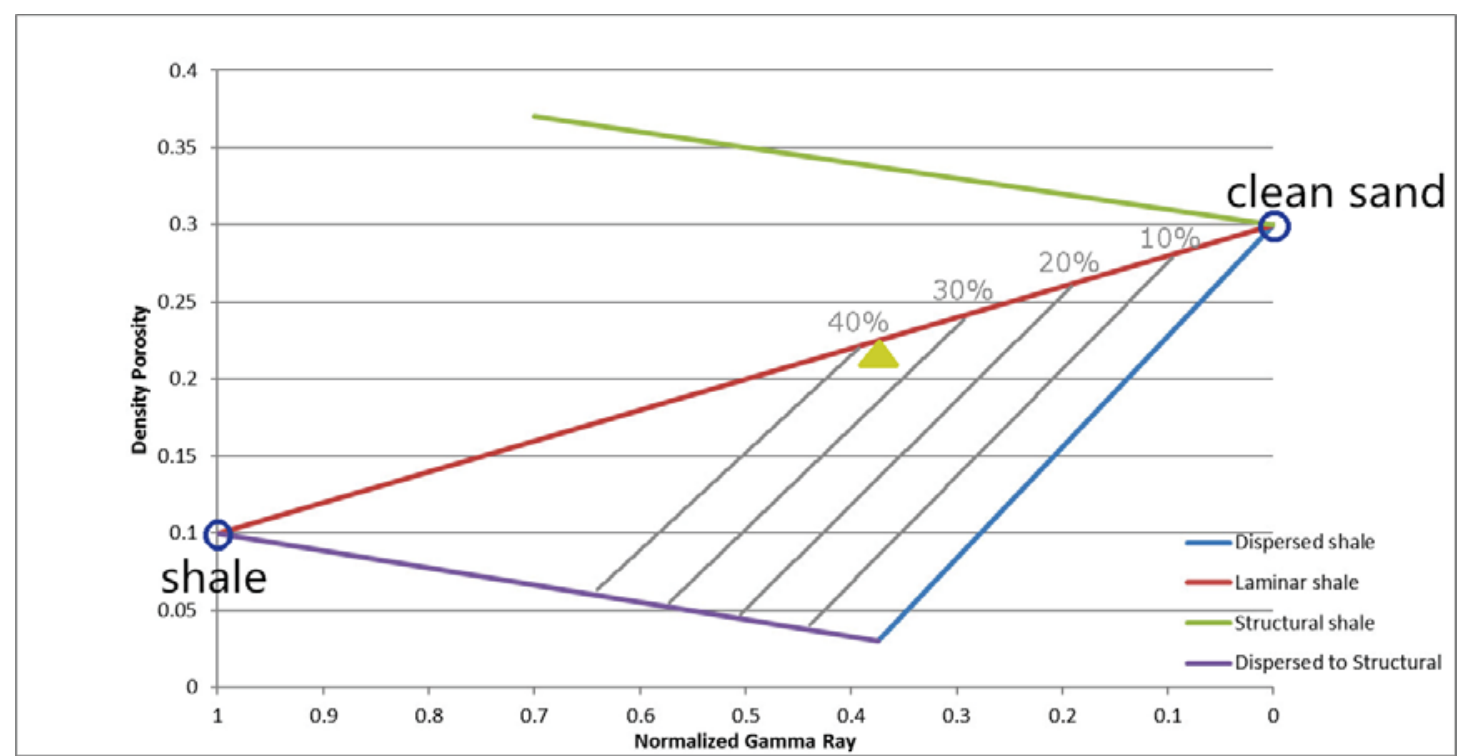

Figure 4.2 Thomas Stieber plot of sandstone where porosities of clean sand and shale are 0.3 and 0.1 , and normalized gamma-ray of clean sand and shale are 0 and 1 respectively. Blue line represents dispersed shale, red line represents laminated shale, green line represents structural shale and purple line represents dispersed shale changes to structural shale. The yellow triangle is identified with normalized gamma-ray at 0.4 , density porosity at 0.21 , and laminated shale content at $38 \%$.

The location of the triangle corners in the Thomas Stieber method are dependent on the gamma-ray and density responses of the sand and shale. In order to apply the method to carbonates in the Trenton-Black River limestone, I assume that the two end-members are clean carbonate and pure shale, and obtained the appropriate values from the logs. For example, Figure 4.3 shows a log plot of well USA ST NORMAN NO 1-29 for the Utica shale and Trenton limestone, from which we can obtain end-member properties. The clean carbonate exhibits porosity of 0.07 at depth 6465 feet where the gamma-ray response is 15 API. For the pure shale, I used the density porosity in Utica shale of 0.09 , obtained at depth 
6238 feet where the gamma-ray response is 150 API. These depths are indicated on the log plot in Figure 4.3, where the gamma-ray values are the minimum and maximum.

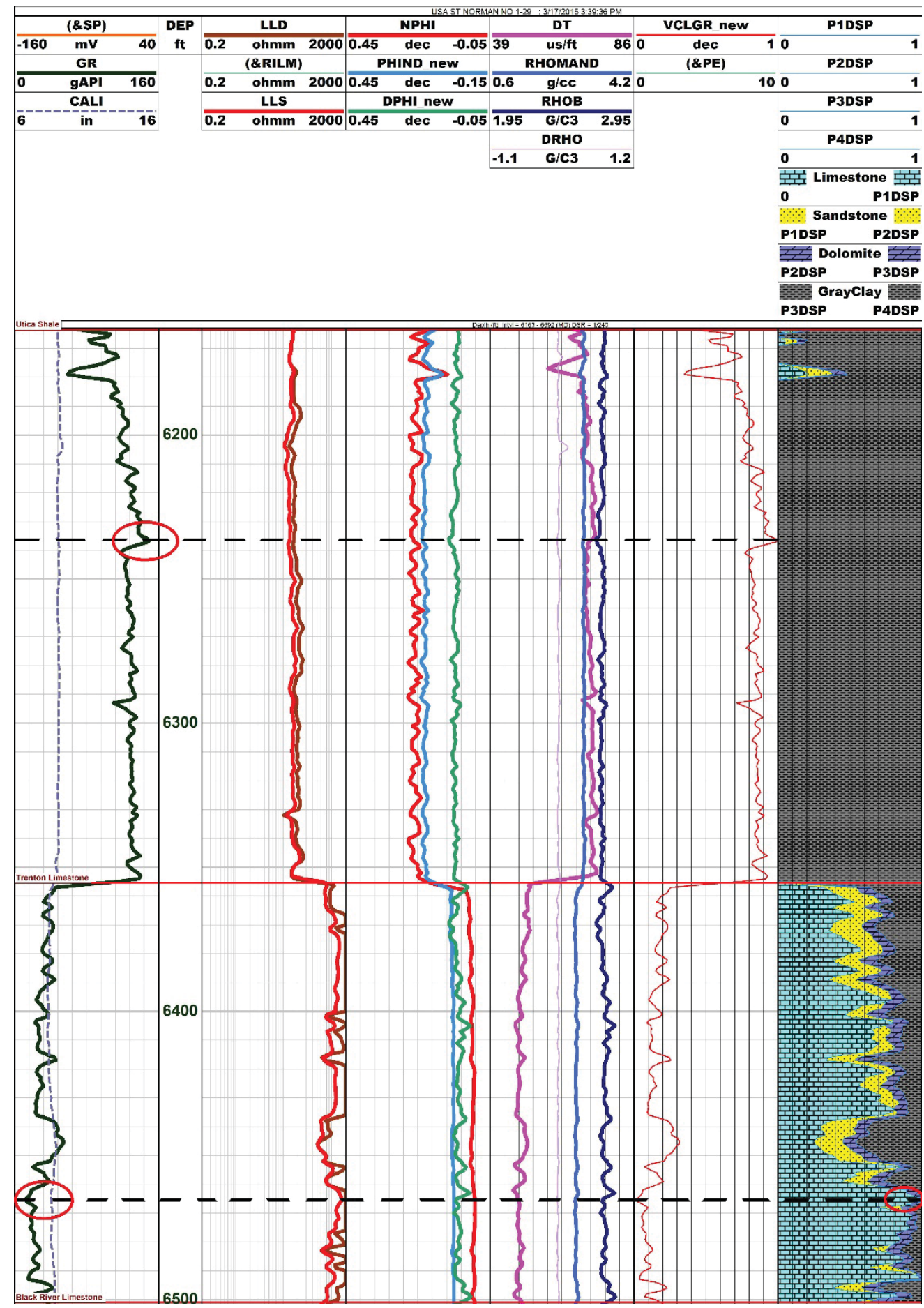


Figure 4.3 Log plot of well USA ST NORMAN NO 1-29 with Utica Shale and Trenton limestone. The green line in the first track is the gamma-ray curve, the green line in the fourth track is the DPHI curve, dotted lines are at depths of clean carbonate and pure shale, and the circled depths provide the gamma-ray readings and lithology for clean carbonate (lower point) and pure shale (shallower point).

These values provide the end points for the upper side of the triangle (the laminated shale line) in the Thomas Stieber method. To determine the lower corner of the triangle, I add dispersed shale into the pore space of clean carbonate until the maximum amount of dispersed shale equals the original porosity of clean carbonate.

Following the method used to read values and apply the equations of the Thomas Stieber method, detailed in Appendix II, I obtained the density porosity of clean carbonate and pure shale and the minimum porosity of each well independently. Then I created my own Thomas Stieber plots for these carbonates. Figure 4.4 displays an example for well USA ST NORMAN NO 1-29. The colored data points in this figure follow a trend along the laminated shale line. There are fourteen wells displaying this kind of distribution in our sample. Table 4.1 summarizes the results of Thomas Stieber and those of the crossplot method for lithology determination. 


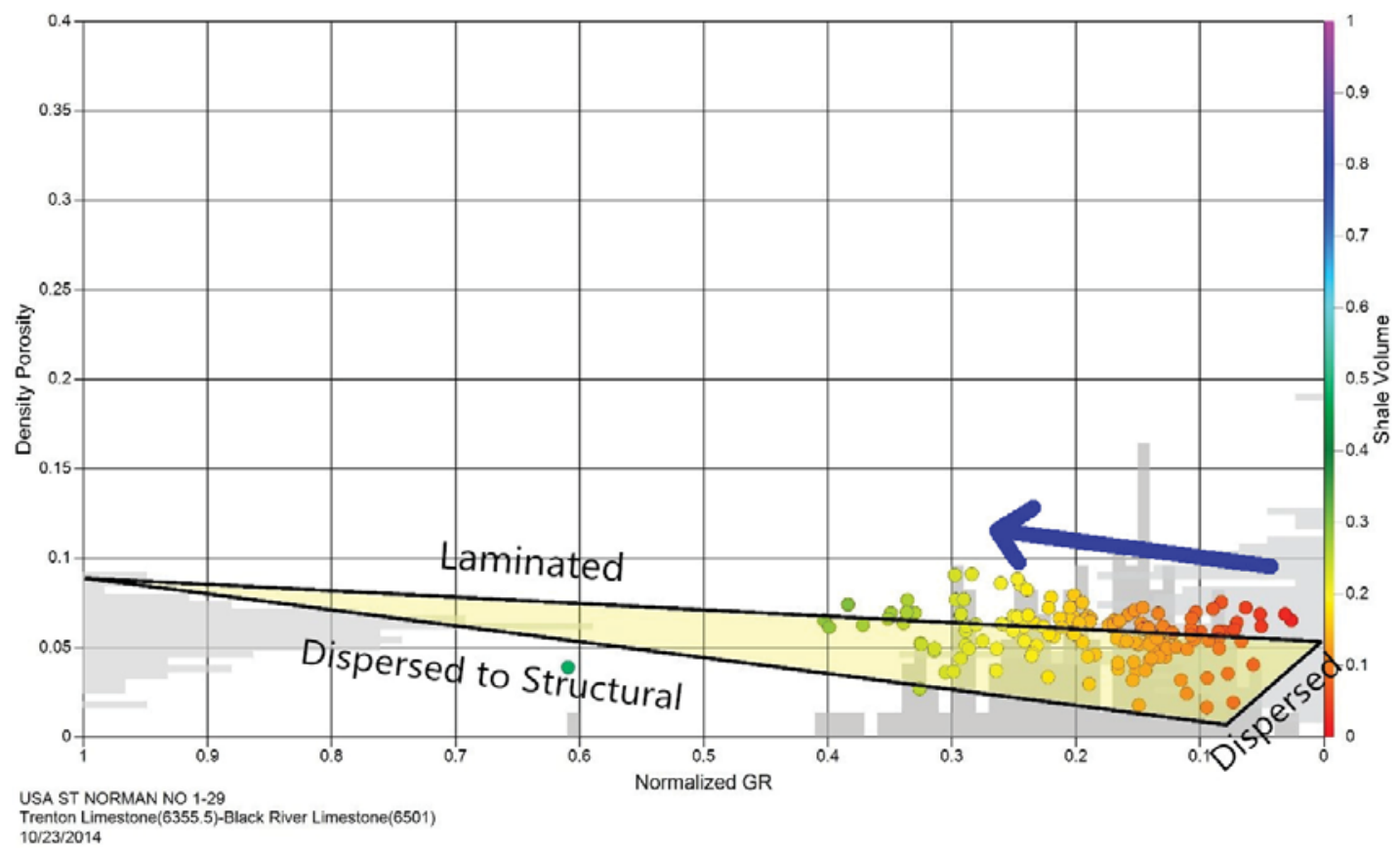

Figure 4.4 Thomas Stieber plot of well USA ST NORMAN NO 1-29 with Trenton-Black River limestone, between normalized gamma-ray and density porosity. The color bar shows the shale volume (which also correlates with location on the horizontal axis). Black lines represent dispersed shale, laminated shale and dispersed to structural shale. Data points fall on the laminated shale line.

Table 4.1 List of 26 wells and results of crossplots and Thomas Stieber

\begin{tabular}{|c|c|c|c|c|}
\hline Well Name & Pure Limestone & $\begin{array}{c}\text { Partially } \\
\text { Dolomitized } \\
\text { Limestone }\end{array}$ & $\begin{array}{c}\text { Shaly } \\
\text { Limestone }\end{array}$ & $\begin{array}{c}\text { Laminated } \\
\text { Shale }\end{array}$ \\
\hline ARMSTRONG NO 1-8 & $\sqrt{ }$ & & & \\
\hline FERRIS AND ST ORANGE NO 1 28 & $\sqrt{ }$ & & & \\
\hline JONES UNIT B NO 3-7 & $\sqrt{ }$ & & & $\sqrt{ }$ \\
\hline Kennedy 1-15 & $\sqrt{ }$ & $\sqrt{ }$ & \\
\hline USA ST NORMAN NO 1-29 & $\sqrt{ }$ & $\sqrt{ }$ & $\sqrt{ }$ \\
\hline BONINE NO 1-22 & & $\sqrt{ }$ & \\
\hline ENGLE NO 2-32 & & & & \\
\hline REYNOLDS NO 2-11 & & & & \\
\hline BRANDT NO 1-34 & & & & \\
\hline BALLENTINE UNIT NO 1 35 & & & & \\
\hline
\end{tabular}




\begin{tabular}{|c|l|l|l|l|}
\hline COATES NO 1 24 & & & $\sqrt{ }$ & $\sqrt{ }$ \\
\hline CONSUMERS POWER CO NO 1 34 & & & $\sqrt{ }$ & \\
\hline DOORNBOS NO 5-30 & & & $\sqrt{ }$ & $\sqrt{ }$ \\
\hline GERNAAT ET AL NO 2 19 & & & $\sqrt{ }$ & $\sqrt{ }$ \\
\hline GEORGE P DORR NO 1 & & & $\sqrt{ }$ & $\sqrt{ }$ \\
\hline HAROUTUNIAN UNIT NO 14 & & & $\sqrt{ }$ & \\
\hline HUBER NO 1 26 & & & $\sqrt{ }$ & $\sqrt{ }$ \\
\hline Kelly 1 & & & $\sqrt{ }$ & $\sqrt{ }$ \\
\hline MARTIN NO 1-15 & & & $\sqrt{ }$ & $\sqrt{ }$ \\
\hline MAIDENS ET AL NO 5 25 & & & $\sqrt{ }$ & $\sqrt{ }$ \\
\hline N MICH LAND AND OIL 1-27 & & & $\sqrt{ }$ & $\sqrt{ }$ \\
\hline PREVOST ET AL NO 1-11 & & & $\sqrt{ }$ & $\sqrt{ }$ \\
\hline SNOWPLOW NO 9 & & & $\sqrt{ }$ & $\sqrt{ }$ \\
\hline VICTORY NO 2 26 & & & & \\
\hline CAMERON NO 1 10 & & & & $\sqrt{ }$ \\
\hline ST MICHELL NO 1-31 & & & & $\sqrt{ }$ \\
\hline
\end{tabular}

As we can see from the table, most wells with shaly limestone are displayed in laminated shale, and it may be safe to conclude that when shale occurs in the Trenton-Black River limestone formation, it tends to be laminated. Wilson's (2001) study described core from Hunt Winterfield Deep A-1, and identified these facies in the Trenton-Black River formations: hardgrounds, laminated shale beds, compacted shale seams, and crosslaminated bioclastic units. This also suggests that the shale is laminated when it occurs.

In order to obtain more details about the laminated shale beds in Trenton-Black River formations, I analyzed the logs from one well included in Wilson's (2001) study: Hunt Winterfield Deep A-1, Figure 4.5 shows the neutron-sonic crossplot; gamma-ray values, neutron porosity and sonic transit time all increase in the direction of the arrow. The gamma-ray increase alone demonstrates the presence of shale, while the change in other properties can be explained by some sort of systematic variation in lithology, but which cannot be identified by this plot alone. 


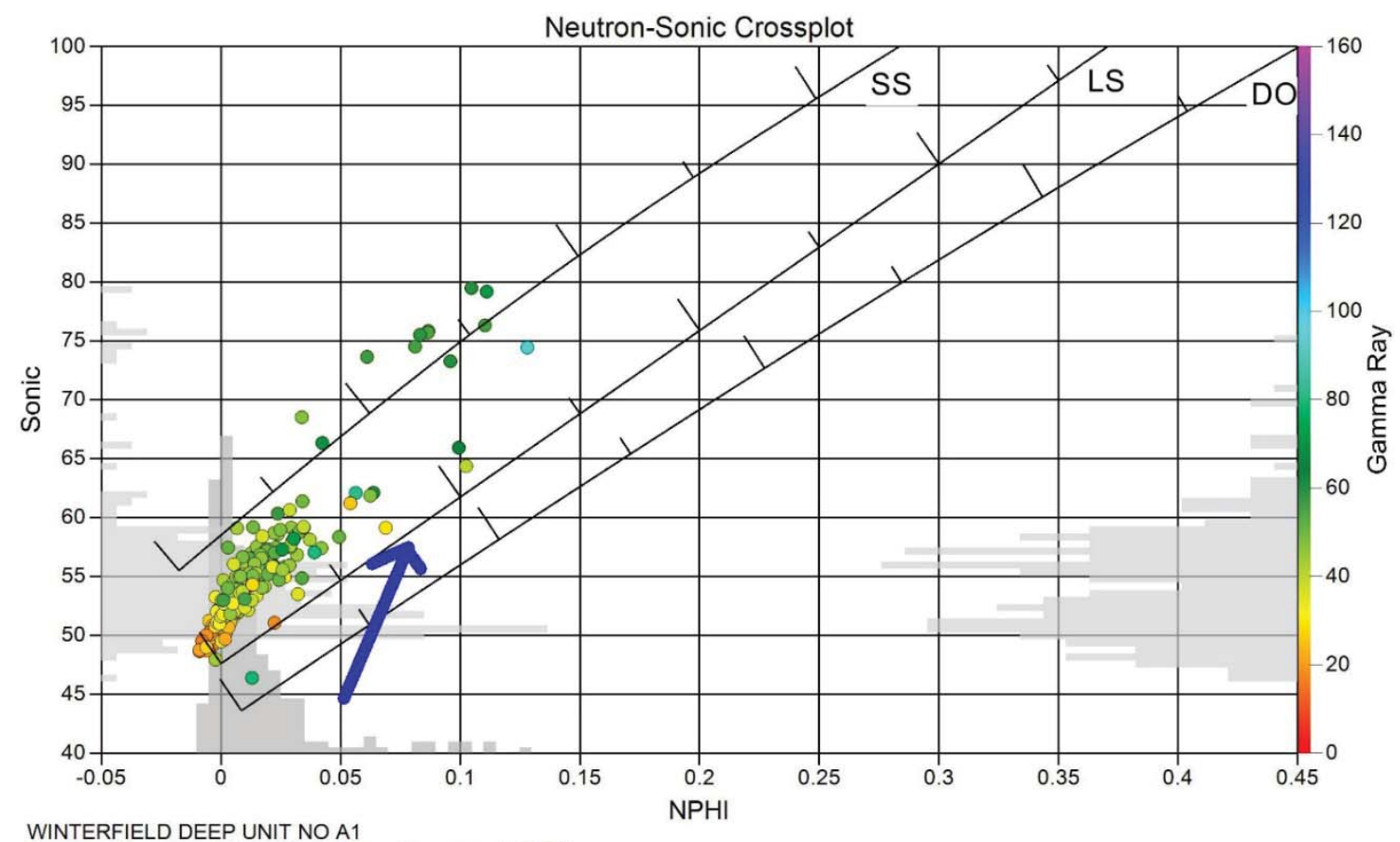

WINTERFIELD DEEP UNIT NO A1

Trenton Limestone(9901)-Black River Limestone(10159)

$10 / 28 / 2014$

Figure 4.5 Neutron-sonic crossplot of well Winterfield Deep Unit NO A1 in Trenton-Black River limestone. Both neutron porosity and sonic transit time increased in the arrow's direction, which the gamma-ray values indicate as increasing in shale content.

The Thomas Stieber plot for well Winterfield Deep Unit NO A1 was created, picking the Trenton-Black River formations. In Figure 4.6, the density porosities of clean carbonate and pure shale are 0.61 and 0.66 , and the minimum density porosity (which is the product of these values) is 0.40 . The normalized gamma-ray value for the minimum porosity point can be calculated from the equation in Appendix II as 0.74 API. In the direction of the arrow, with increasing shale volume, the content of laminated shale increases. This distribution of the data points can be used to support Wilson's (2001) summary. 


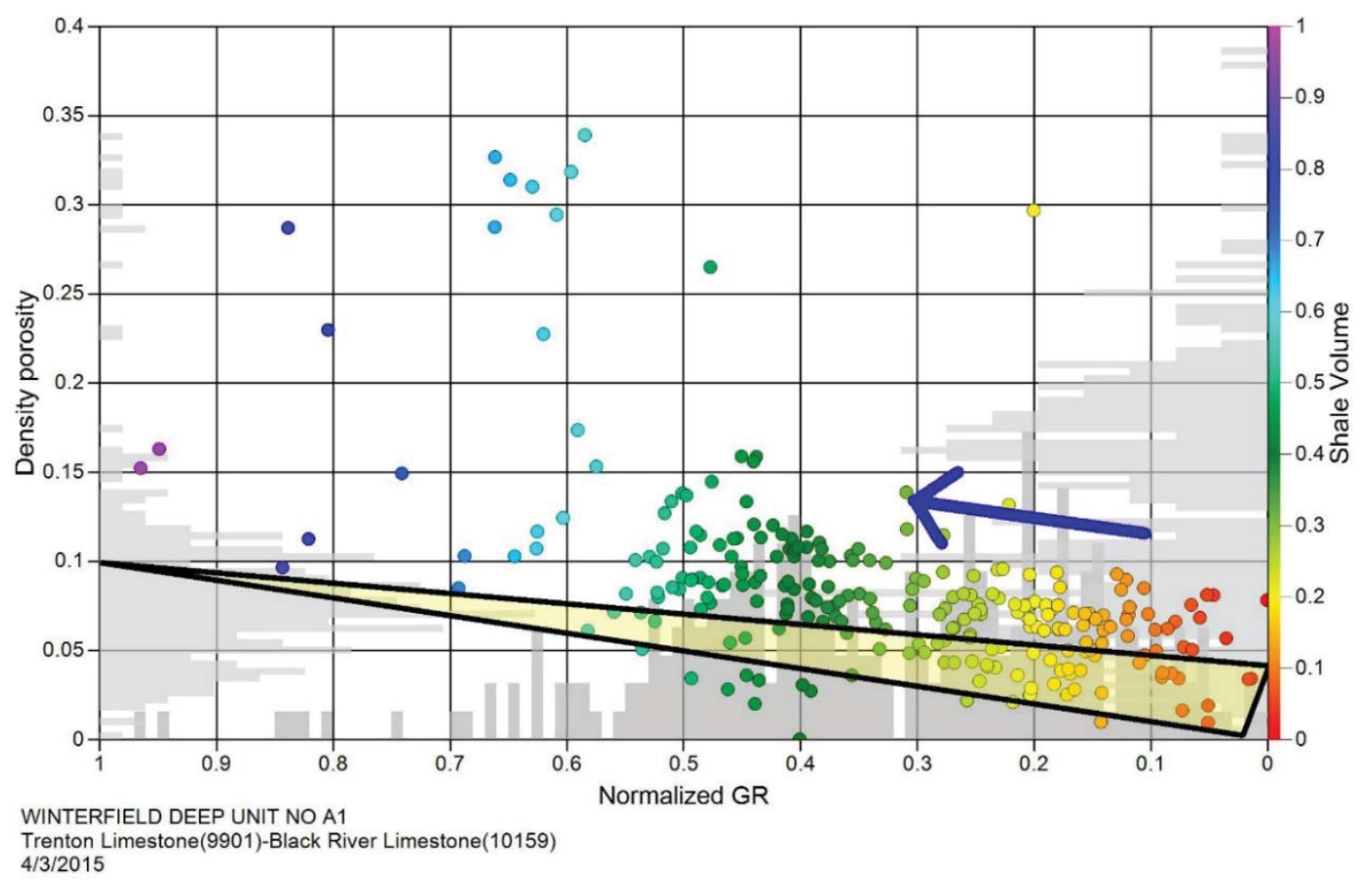

Figure 4.6 Thomas Stieber plot of well Winterfield Deep Unit NO A1 in Trenton-Black River limestone. The colored data points distribute in the arrow's direction on the laminated shale line, indicating the content of laminated shale increases.

\section{Discussion}

This work applied petrophysical analysis to the Trenton-Black River limestone formation. The methods used consisted of conventional crossplot techniques for mineral identification, a modified mineral identification approach, and an extension of the Thomas Stieber method for shale distribution.

Neutron-density and neutron-sonic crossplots can indicate lithology changes and the presence of shale in formation. But there are some limitations in the well log data. The log curves were measured and run by different companies, so there are different charts used to determine some parameters, which would affect the accuracy of results. 
Compared to three-mineral and four-mineral identification, the modified mineral identification gives reasonable good results by removing the effect of shale. The correction makes the results more reliable. But the data quality of some wells is poor, which may cause some uncertainties and errors. There are thirty-five wells used in this work, but nine of these wells do not have a PEF log, and mineral components cannot be calculated without the PEF log. Less data would also cause less accurate results of mineral identification.

In order to have more detailed information about the constituent components of carbonate, the Thomas Stieber method was applied to the Trenton-Black River limestone formation. The Thomas Stieber method is a combination of a gamma-ray log and a density porosity $\log$, distinguishing the types of shale. From the distribution of data points on the Thomas Stieber plot, it is easy to see the presence of laminated shale in this formation.

\section{Conclusion}

The Trenton-Black River limestone formation is composed primarily of calcite, dolomite, clay and small amounts of quartz. The greatest depth to the top of this formation is found in the central basin, which has a higher shale fraction. But the maximum thickness is in the eastern basin, not at the center, and it decreases gradually to the western part. In the southeastern and the south central basin, limestone and dolomite are both present, but in the west and southwest of the basin, the dolomite increases.

In order to obtain the description of the mineral composition and explain the lithology changes, neutron-density and neutron-sonic crossplots are applied to Trenton-Black River limestone. Each of the two crossplots gave three quite different results: pure limestone, partially dolomitized limestone and shaly limestone.

Mineral identification is necessary for detailed lithology interpretation. The M-N plot, MID plot, Qmaa Vs. $U_{\text {maa }}$ MID plot, PEF plot and the modified mineral identification method are involved in this work. The modified mineral identification of Islam (2011) showed results 
similar to those of the crossplot techniques, demonstrating the presence of dolomite and shale in the Trenton-Black River limestone formation.

The Thomas Stieber method is a model for the porosity of sand-shale sequences, which can be used to parse shaly sand into three different types of shale: dispersed, laminated and structural. This method is commonly used for clastic rocks, in order to apply its application in carbonates, the Thomas Stieber approach was applied to the Trenton-Black River limestone formation. Under the similar assumption that the rocks have two end-members of clean carbonate and pure shale, my own plot for carbonates was created, displaying the presence of laminated shale. Combined with Wilson's (2001) study, his descriptions of core from the Trenton-Black River formation can support the result from the Thomas Steiber plot. There is a conclusion that where there is shale in the Trenton-Black River limestone formation, it tends to be laminated shale. 


\section{References}

Banas, R. M. 2011. Geophysical and geological analysis of the Collingwood Member of the Trenton Formation. In Geological/Mining Engineering \& Sciences. Thesis (M.S.) - Michigan Technological University.

Catacosinos, P., P. Daniels Jr \& W. Harrison III (1991) Structure, stratigraphy, and petroleum geology of the Michigan Basin. Interior cratonic basins: AAPG Memoir, $51,561-601$.

Coburn, T. C., P. A. Freeman \& E. D. Attanasi (2012) Empirical methods for detecting regional trends and other spatial expressions in Antrim Shale gas productivity, with implications for improving resource projections using local nonparametric estimation techniques. Natural resources research, 21, 1-21.

Fara, D. \& B. Keith (1984) Depositional Facies and Diagenetic History of Trenton Limestone in Northern Indiana: ABSTRACT. AAPG Bulletin, 68, 1919-1919.

Howell, P. D. \& B. A. van der Pluijm (1990) Early history of the Michigan basin: Subsidence and Appalachian tectonics. Geology, 18, 1195-1198.

Islam, N. 2011. Sonic log prediction in carbonates. In Geological/Mining Engineering \& Sciences. Thesis (M.S.) - Michigan Technological University.

Ives, R. E. 1960. Trenton-Black River Formation Developments in Michigan. Vol. 2 No.1 pp. 79-86. The Interstate Oil Compact Commission Committee Bulletin.

Minear, J. W. 1982. Clay models and acoustic velocities. In SPE Annual Technical Conference and Exhibition. Society of Petroleum Engineers.

Rancourt, C. 2009. " Collingwood" Strata in South-central Ontario-A Petrophysical Chemostratigraphic Approach to Comparison and Correlation Using Geophysical Borehole Logs.

Rupp, J. 1997. Tectonic features of Indiana. In Indiana Geological Survey, Tectonic Features. Indiana Geological Survey.

Schlumberger. 1991. Log interpretation principles/applications. Schlumberger Educational Services.

Talley, C. J. 2014. Oil \& GAS NEWSLETTER. In Michigan State University Extension Farm Management. 
Thomas, E. \& S. Stieber. 1975. The distribution of shale in sandstones and its effect upon porosity. In SPWLA 16th Annual Logging Symposium, 4-7. Society of Petrophysicists and Well-Log Analysts.

Wylie, A. S., Jr, J. R. Wood \& W. B. Harrison, III (2004) Michigan Trenton-Black River opportunities identified with sample attribute mapping. Oil \& Gas Journal, 2004, ProQuest pg. 29.

\section{Appendix I: Crossplots \& Mineral Identification}

There are many ways to identify minerals from logs. The methods that are addressed in the text are summarized here, using conventional approaches found in standard logging charts and algorithms.

\section{Density Porosity and Sonic Porosity}

Density porosity is related to matrix density, bulk density, and fluid density. Sonic density is determined with Wyllie Time-Average equation.

$\mathrm{DPHI}=\frac{R h o M-\mathrm{eb}}{R h o M-\mathrm{ef}}$

DHPI = Density porosity

RhoM = Matrix density (I used $2.71 \mathrm{gm} / \mathrm{cc}$ )

$\mathrm{Qb}_{\mathrm{b}}=$ Bulk density (logging curve RHOB)

$\varrho_{\mathrm{f}}=$ Pore fluid density $(\mathrm{I}$ used $1.1 \mathrm{~g} / \mathrm{cc})$

$\mathrm{SPHI}=\frac{D T-D T M A}{D T F-D T M A}$

SPHI $=$ Sonic density

$\mathrm{DT}=$ Reading on the sonic log (logging curve DT) 
DTMA = Matrix transit time (I used $55 \mu \mathrm{sec} / \mathrm{ft}$ )

$\mathrm{DTF}=$ Fluid transit time $(\mathrm{I}$ used $185 \mu \mathrm{sec} / \mathrm{ft})$

\section{M-N Plot}

The M-N plot is used to identify minerals based on the porosity indicators from sonic and neutron logs, normalized by the density log.

$\mathrm{M}=\frac{t_{f}-t}{\varrho_{b}-\varrho_{f}} * 0.01$

$\mathrm{N}=\frac{\emptyset_{N f}-\emptyset_{N}}{\varrho_{b}-\varrho_{f}}$

$\mathrm{t}_{\mathrm{f}}=$ Pore fluid transit time (I used $\left.185 \mu \mathrm{sec} / \mathrm{ft}\right)$

$\mathrm{t}=$ Interval transit time (logging curve DT)

$Q_{b}=$ Bulk density (logging curve RHOB)

$\varrho_{\mathrm{f}}=$ Pore fluid density $(\mathrm{I}$ used $1.1 \mathrm{~g} / \mathrm{cc})$

$\emptyset_{\mathrm{Nf}}=$ Fluid neutron porosity (I used 1)

$\emptyset_{\mathrm{N}}=$ Neutron porosity (logging curve NPHI)

Sandstone: $\mathrm{M}=0.835 \mathrm{~N}=0.667$

Limestone: $\mathrm{M}=0.854 \mathrm{~N}=0.621$

Dolominte: $\mathrm{M}=0.8 \mathrm{~N}=0.528$

\section{MID Plot}

The apparent total porosity, apparent matrix transit time and apparent grain density are required for this plot. 
$\varrho_{\text {maa }}=\frac{\varrho_{b}-\emptyset_{t a \varrho_{f}}}{1-\emptyset_{t a}}$

Qmaa $=$ Apparent grain density

$\emptyset_{\mathrm{ta}}=$ Apparent total porosity (logging curve PHIND)

$\mathrm{t}_{\mathrm{maa}}=\frac{t-\emptyset_{t a} t_{f}}{1-\emptyset_{t a}}$

$\mathrm{t}_{\mathrm{maa}}=$ Apparent matrix transit time

\section{4. @maa vs. U maa MID}

The @maa vs. $U_{\text {maa }}$ MID plot is similar with MID plot, identifying lithology with data from litho-density log. It uses the apparent matrix grain density (RHOMAND) and the apparent matrix volumetric cross section (UMA).

$\mathrm{UMA}=\frac{P_{e} \varrho_{e}-\emptyset_{t a} U_{f}}{1-\emptyset_{t a}}$

$Q_{e}=\frac{\varrho_{b}+0.1883}{1.0704}$

$\mathrm{UMA}=$ Apparent matrix volumetric cross section

$\mathrm{P}_{\mathrm{e}}=$ Photoelectric absorption cross section (logging curve PEF)

$\varrho_{\mathrm{e}}=$ Electron density

$\mathrm{U}_{\mathrm{f}}=$ Volumetric cross section of fluid (I used $0.398 \mathrm{~b} / \mathrm{cc}$ )

\section{Modified Mineral Identification(Islam 2011)}

This identification is modified by combining both 3-mineral and 4-mineral identification approach and removing the shale effect from all the logs. 
Calculating shale volume

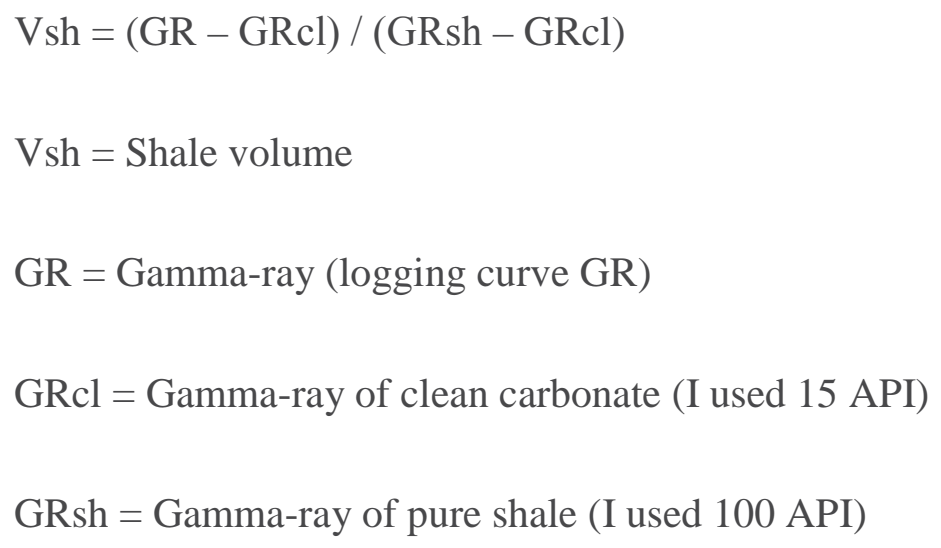

Else

$\mathrm{RHOBcl}=\mathrm{RHOB}$

Where

$\mathrm{RHOB}=$ Bulk density value from logs $(\mathrm{gm} / \mathrm{cc})$

RHOBcl $=$ Density value in clean formation $(\mathrm{gm} / \mathrm{cc})$

RHOBsh $=$ Shale Density Value (I used $2.65 \mathrm{gm} / \mathrm{cc}$ )

If $(\mathrm{RHOBcl}>3)$

$\mathrm{RHOBcl}=3$

Else

If $(\mathrm{RHOBcl}<2)$

$\mathrm{RHOBcl}=2$

Else 
$\mathrm{RHOBcl}=\mathrm{RHOBcl}$

Cleaning PEF

If $\mathrm{Vsh}<1$

$\mathrm{PEFcl}=(\mathrm{PEF}-\mathrm{PEFsh} * \mathrm{Vsh}) /(1-\mathrm{Vsh})$

Else

$\mathrm{PEFcl}=\mathrm{PEF}$

Where

$\mathrm{PEF}=$ Photoelectric absorption cross section $\log (\mathrm{B} / \mathrm{E})$

PEFsh $=$ PEF value for shale $($ I used $3.50 \mathrm{~B} / \mathrm{E})$

$\mathrm{PEFcl}=\mathrm{PEF}$ value in clean formation $(\mathrm{B} / \mathrm{E})$

Cleaning neutron porosity

If $\mathrm{Vsh}<1$

$\mathrm{NPHIcl}=(\mathrm{NPHI}-\mathrm{NPHIsh} * \mathrm{Vsh})$

Else

$\mathrm{NPHIcl}=\mathrm{NPHI}$

Where

NPHIcl $=$ Neutron porosity in clean formation

$\mathrm{NPHI}=$ Neutron porosity from logging data

NPHIsh $=$ Neutron porosity in shale $($ I used 0.25)

Cleaning density porosity

PHIDcl $=($ RhoM - RHOBcl $) /($ RhoM - RhoF $)$

PHIDcl $=$ Density porosity in clean formation

RhoM = Matrix density (I used $2.71 \mathrm{gm} / \mathrm{cc}$ ) 
RhoF = Fluid density (I used $1.1 \mathrm{gm} / \mathrm{cc}$ )

Limiting density porosity

If PHIDcl > 0.5

PHIDcl $=0.5$

Else

PHIDcl $=$ PHIDcl

Limiting neutron porosity

If NPHIcl $>0.5$

$\mathrm{NPHIcl}=0.5$

Else

$\mathrm{NPHIcl}=\mathrm{NPHIcl}$

Clean average porosity

PHIAcl $=($ PHIDcl + NPHIcl $) / 2$

PHIAcl $=$ Average porosity in clean formation

Calculating UMA and DGA

$\mathrm{Ucl}=\mathrm{PEFcl}^{*}((\mathrm{RHOBcl}+0.1883) / 1.07)$

$\mathrm{UMAcl}=(\mathrm{Ucl}-0.398 * \mathrm{PHIAcl}) /(1-\mathrm{PHIAcl})$

DGAcl $=($ RHOBcl-PHIAcl $) /(1-\mathrm{PHIAcl})$

$\mathrm{Ucl}=$ Volumetric cross section in clean formation $(\mathrm{b} / \mathrm{cc})$

$\mathrm{UMAcl}=$ Apparent matrix volumetric cross section in clean formation $(\mathrm{b} / \mathrm{cc})$

DGAcl $=$ Apparent dry grain density in clean formation $(\mathrm{gm} / \mathrm{cc})$

Calculating bulk volume

$\mathrm{Vcl}=1-\mathrm{Vsh}$ 
$\mathrm{Vcl}=$ Bulk volume in clean formation

Calculating mineral fractions(Wylie, Wood and Harrison 2004)

$\mathrm{P} 1 \mathrm{cl}=(-\mathrm{D} 2 * \mathrm{UMAcl}+\mathrm{D} 3 * \mathrm{UMAcl}+\mathrm{DGAcl} * \mathrm{U} 2-\mathrm{Vcl} * \mathrm{D} 3 * \mathrm{U} 2-\mathrm{DGAcl} * \mathrm{U} 3+\mathrm{Vcl} * \mathrm{D} 2 * \mathrm{U} 3) /(-$ $\mathrm{D} 2 * \mathrm{U} 1+\mathrm{D} 3 * \mathrm{U} 1+\mathrm{D} 1 * \mathrm{U} 2-\mathrm{D} 3 * \mathrm{U} 2-\mathrm{D} 1 * \mathrm{U} 3+\mathrm{D} 2 * \mathrm{U} 3)$

If $\mathrm{P} 1 \mathrm{cl}<0$

$\mathrm{P} 1 \mathrm{cl}=0$

If $\mathrm{P} 1 \mathrm{cl}>1$

$\mathrm{P} 1 \mathrm{cl}=1$

$\mathrm{P} 2 \mathrm{cl}=(-\mathrm{D} 1 * \mathrm{UMAcl}+\mathrm{D} 3 * \mathrm{UMAcl}+\mathrm{DGAcl} * \mathrm{U} 1-\mathrm{Vcl} * \mathrm{D} 3 * \mathrm{U} 1-\mathrm{DGAcl} * \mathrm{U} 3+\mathrm{Vcl} * \mathrm{D} 1 * \mathrm{U} 3) /(-$ $\mathrm{D} 2 * \mathrm{U} 1+\mathrm{D} 3 * \mathrm{U} 1+\mathrm{D} 1 * \mathrm{U} 2-\mathrm{D} 3 * \mathrm{U} 2-\mathrm{D} 1 * \mathrm{U} 3+\mathrm{D} 2 * \mathrm{U} 3)$

If $\mathrm{P} 2 \mathrm{cl}<0$

$\mathrm{P} 2 \mathrm{cl}=0$

If $\mathrm{P} 2 \mathrm{cl}>1$

$\mathrm{P} 2 \mathrm{cl}=1$

$\mathrm{P} 3 \mathrm{cl}=(-\mathrm{D} 1 * \mathrm{UMAcl}+\mathrm{D} 2 * \mathrm{UMAcl}+\mathrm{DGAcl} * \mathrm{U} 1-\mathrm{Vcl} * \mathrm{D} 2 * \mathrm{U} 1-\mathrm{DGAcl} * \mathrm{U} 2+\mathrm{Vcl} * \mathrm{D} 1 * \mathrm{U} 2) /(-$ $\mathrm{D} 2 * \mathrm{U} 1+\mathrm{D} 3 * \mathrm{U} 1+\mathrm{D} 1 * \mathrm{U} 2-\mathrm{D} 3 * \mathrm{U} 2-\mathrm{D} 1 * \mathrm{U} 3+\mathrm{D} 2 * \mathrm{U} 3)$

If $\mathrm{P} 3 \mathrm{cl}<0$

$\mathrm{P} 3 \mathrm{cl}=0$

If $\mathrm{P} 3 \mathrm{cl}>1$

$\mathrm{P} 3 \mathrm{cl}=1$

$\mathrm{S}=(\mathrm{P} 1 \mathrm{cl}+\mathrm{P} 2 \mathrm{cl}+\mathrm{P} 3 \mathrm{cl})$

$\mathrm{P} 1 \mathrm{cl}=(\mathrm{P} 1 \mathrm{cl} * \mathrm{Vcl}) / \mathrm{S}$

$\mathrm{P} 2 \mathrm{cl}=(\mathrm{P} 2 \mathrm{cl} * \mathrm{Vcl}) / \mathrm{S}$

$\mathrm{P} 3 \mathrm{cl}=(\mathrm{P} 3 \mathrm{cl} * \mathrm{Vcl}) / \mathrm{S}$ 


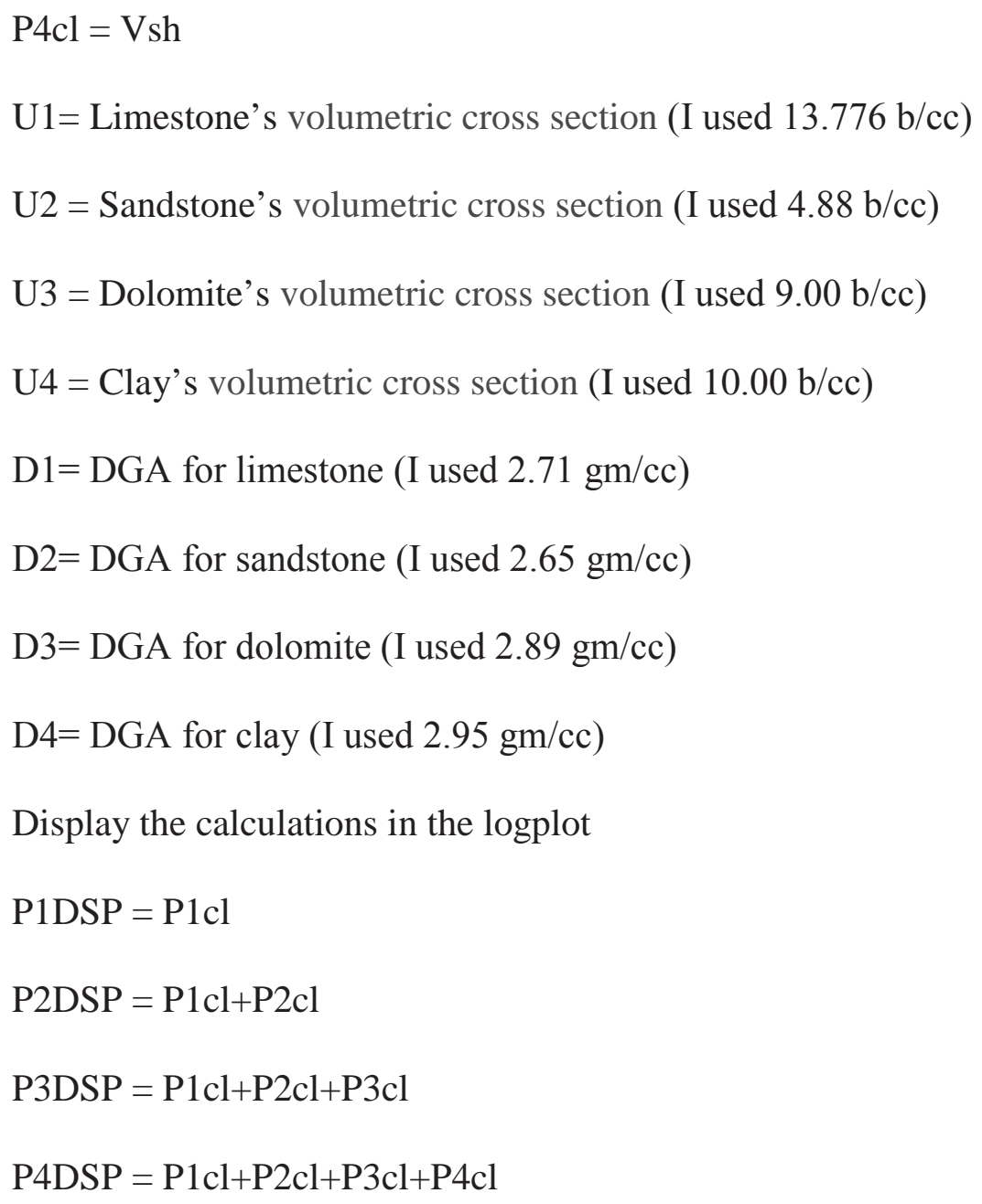

\section{Appendix II: Thomas Stieber (Thomas and Stieber 1975)}

Thomas Stieber method uses a combination of density log and gamma-ray log. Equations and parameters to calculate gamma-ray, shale volume, and porosity for dispersed shale, laminated shale and structural shale are introduced in this part.

\section{Dispersed Shale}

Dispersed shale accumulates to the grains of the sandstone, which can decrease effective porosity, permeability and fluid mobility. 
$\Gamma_{\mathrm{d}}=\Gamma_{\mathrm{sd}}+\mathrm{X}_{\mathrm{sh}} \Gamma_{\mathrm{sh}}$

$\Gamma_{\mathrm{d}}=$ Radioactive count rate of dispersed shale (API units)

$\Gamma_{\mathrm{sd}}=$ Radioactive count rate of clean sand (I used $\left.100 \mathrm{API}\right)$

$\mathrm{X}_{\mathrm{sh}}=$ Shale volume fraction

$\Gamma_{\mathrm{sh}}=$ Radioactive count rate of shale (I used 15 API)

When $\mathrm{X}_{\mathrm{sh}}=0, \Gamma_{\mathrm{d}}=\Gamma_{\mathrm{sd}}$, so $\Gamma_{\mathrm{d}(\min )}=\Gamma_{\mathrm{sd}}$

When $X_{\mathrm{sh}(\max )}=\emptyset_{\mathrm{sd},} \Gamma_{\mathrm{d}(\max )}=\Gamma_{\mathrm{sd}}+\emptyset_{\mathrm{sd}} \Gamma_{\mathrm{sh},} \emptyset_{\mathrm{d}(\min )}=\emptyset_{\mathrm{sd}} * \emptyset_{\mathrm{sh}}$

$\emptyset_{\text {sd }}=$ Original porosity of clean sand

$\emptyset_{\text {sh }}=$ Shale porosity

\section{Laminated Shale}

Laminated shale exists as layers in the rock. Since the effective porosity and permeability of shale are zero, this type of shale can decrease the overall porosity and permeability, but it has no influence on each individual sand bed.

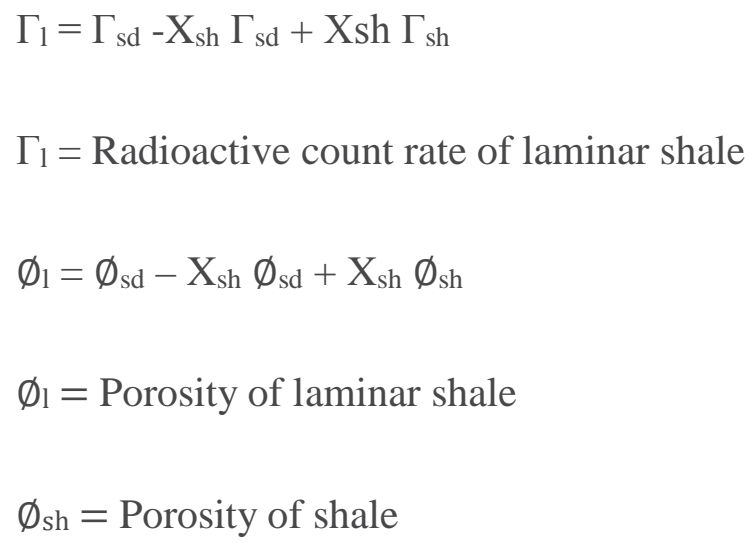

\section{Structural Shale}


Structural shale takes the place of sand grains, it can be considered as part of the rock. It has no effect on porosity and permeability, but it does not occur frequently.

$\Gamma_{\mathrm{s}}=\Gamma_{\mathrm{sd}}-\mathrm{X}_{\mathrm{sh}} \Gamma_{\mathrm{sd}}+\mathrm{X}_{\mathrm{sd}} \Gamma_{\mathrm{sh}}$

$\Gamma_{\mathrm{s}}=$ Radioactive count rate of structural shale

$\emptyset_{\mathrm{s}}=\emptyset_{\mathrm{sd}}+\mathrm{X}_{\mathrm{sh}} \emptyset_{\mathrm{sh}}$

$\emptyset_{\mathrm{s}}=$ Porosity of structural shale

\section{Normalized Gamma-ray}

Normalized GR $=\frac{G R-G R c l}{G R s h-G R c l}$ 